\title{
İslâmî Bir Müzakere Etiğinin İmkânı Üzerine: Taha Abdurrahman'ın Şehâdete Dayalı İletișim Teorisi
}

\section{On the Possibility of an Islamic Negotiation Ethics: Taha Abderrahmane's Theory of Communication Based on Testimony}

\section{Güldane GÜNDÜZÖZ*}

Doç. Dr., Kırıkkale Üniversitesi, İslâmi İlimler Fakültesi, Tasavvuf Anabilim Dalı Assoc. Prof., Kırıkkale University, Faculty of Islamic Sciences, Department of Mysticism Kırıkkale / Turkey guldanegunduzoz@kku.edu.tr | https://orcid.org/0000-0003-3007-6746

*Sorumlu Yazar / Corresponding Author

\section{Soner GÜNDÜZÖZ}

Prof. Dr. Ankara Üniversitesi İlahiyat Fakültesi Arap Dili ve Belagati Anabilim Dalı

Professor, Ankara University, Faculty of Theology, Department of Arabic Language and Rhetoric Ankara, Turkey

http://gunduzoz@ankara.edu.tr | https://orcid.org/0000-0002-8369-3388

Article Type / Makale Tipi

Research Article / Araștırma Makalesi

DOI: $10.33420 /$ marife. 905244
Article Information / Makale Bilgisi Received / Gelis Tarihi: 29.03.2021 Accepted / Kabul Tarihi: 11.06.2021 Yayın Tarihi / Published: 30.06.2021

Cite as / Atıf: Gündüzöz, Güldane - Gündüzöz, Soner. “İslâmî Bir Müzakere Etiğinin İmkânı Üzerine: Taha Abdurrahman'ın Şehâdete Dayalı İletișim Teorisi”. Marife 21/1 (2021), 105-129. https://doi.org/10.33420/marife.905244

Plagiarism / Intihal: This article has been reviewed by at least two referees and scanned via a plagiarism software. / Bu makale, en az iki hakem tarafından incelendi ve intihal içermediği teyit edildi.

\section{(c) (1) $\Theta \Theta$}

Copyright / Telif Hakkl: "This article is an open access article distributed under the terms and conditions of the Creative Commons Attribution-NonCommercial-NoDerivatives 4.0 (CC BY-NC-ND 4.0) International License." / "Bu makale Creative Commons Alıntı-GayriTicari-Türetilemez 4.0 (CC BY-NCND 4.0) Uluslar arası Lisansı altında lisanslanmıștır." 


\section{İslâmî Bir Müzakere Etiğinin İmkânı Üzerine: Taha Abdurrahman'ın Şehâdete Dayalı İletişim Teorisi}

\section{Özet}

Taha Abdurrahman, Arap-İslâm dünyasının yaşayan önemli filozoflarından biridir. Eserlerinde bütüncül ve çok yönlü bir İslâmî metodoloji inşa eden Taha Abdurrahman, teo-politik yazıları ile "fizikî ve metafizik bütünlük içerisinde müzakereci bir siyasal iletişim modeli ve İslâmî bir medya teorisi" önermektedir. Bu makale, Taha Abdurrahman'ın bir yönüyle etik, diğer yönüyle teo-politik olan șehâdete dayalı iletișim ve medya teorisi üzerinde yoğunlașmaktadır. Taha Abdurrahman'a göre, beșerî iletişim, metafizik boyutu esas alan bir yapı olarak, bir yönüyle beșerî ve kolektif, diğer yönüyle, ilahî ve vicdanîdir. Referansları bakımından fizik ve metafizik bütünlüğü gerektiren ve Elest Bezmi'ne ulaşan bu iletişim ağı, Taha Abdurrahman'a göre salt istidlâlin ötesine geçmekte, böylece o, iletişim alanında istidlâl ve şehâdet kavramlarını dengeli biçimde istihdam etmek suretiyle yeni bir müzakere etiği, iletişim modeli ve İslâmî bir medya teorisi olușturmaktadır. Son tahlilde bu teori, -vicdan, burhan ve sultan (iktidar) kavramlarının bütünlükçü bir anlayışla ele alınması gerektiğini vurgulamaktadır. Böylece tüm beșerî ilișkilerin etik, estetik ve epistemolojik boyutta homojen bir yapı oluşturması öngörülmektedir.

Genel anlamda demokrasinin bir enstrümanı olan medya alanında ve -farklı versiyonları olmakla beraber- liberteryan teorisyenler tarafindan geliștirilen müzakereci demokrasi kavramı ile ilgili birtakım iletișim teorilerinde dinî epistemolojinin etkisiz hâle getirildiği görülmektedir. Bu teorilerden biri, Taha Abdurrahman'ın, müzakeredeki kolektiflik özelliğine vurgusu nedeniyle inceleme ve mukayese konusu yaptığı Habermas'ın iletişim teorisidir. Aslında dine kayıtsızlık, Jürgen Habermas'ınki gibi demokrasinin müzakereci demokrasiye evirilmiş sivil liberteryan yorumlarında sıkça görülen bir durumdur. Oysaki müzakereci demokraside devlet dışı müzakere alanları, bir iletişim alanı olarak görülmekte, medya, sosyal medya araçları ve dernekler gibi unsurlar, devletin resmî müzakere organı parlamento ile benzer nitelikte, toplumsal iletişimin bir paydașı olarak değerlendirilmektedir. Buna mukabil din olgusuna kayıtsı kalınması paradoksal bir durum oluşturmaktadır.

Taha Abdurrahman, İslâmî bir iletişim modeli ve medya teorisi kurmak için müzakere demokrasisinin önemli temsilcilerinden Jürgen Habermas'ın iletişimsel eylem teorisinden oldukça yararlanmış, fakat aynı zamanda bu teoriye yönelik ciddi elesstirilerde bulunmuştur. Abdurrahman'ın teorisine tasavvufí bir neşve katan nevâfil hadisi, Allah'a teslimiyet ve samimi bir taat ile bağlanmış olan kulun her an yanında Allah'ın inayet ve himayesini hissedeceğini ifade eden kudsî bir hadistir ve hadis daha çok tasavvuf çevrelerinde kabul görmektedir.

Taha Abdurrahman, İslâmî kümülatif bilgi dağarcığını referans almakta ve İslâm düșüncesinin tarihsel hafiza üzerinden üretimine çalışmaktadır. Ne var ki o, bu metodunda söz konusu birikime sadece kolektif ve beșerî uzlaşıya dayalı bir alan olarak bakmamaktadır. Aksine Taha Abdurrahman, insanın kendi derununda hatırasını taşıdığı metafizik hafızaya dayanmaktadır. Dolayısıyla da İslâm toplumunun bilgi üretimi ve iletişim süreçleri salt argümantasyona dayandırlamayacak şekilde vicdanî boyuta kuvvetli atıflar içeren şehâdet kavramıyla da ilgilidir. Taha Abdurrahman'ın çalıșmalarına yön veren en önemli hususlardan biri de dilsel bir paradigmaya dayanan Söz-Eylem Teorisidir. Abdurrahman bu teorisi ile pek çok yönden Batılı kaynakları referans almış olsa da Batıdakinden oldukça farklı bir pragmatik yaklaşım inşa etmektedir. Eserlerinde bütüncül ve çok yönlü bir İslâmî metodoloji inșa eden Taha Abdurrahman, i'timâniyye (ilahî sözleșme ve emanet paradigması) ve tedâvuliyye (pragmatik-söz-eylem kuramı) ekseninde bir düșünce dünyası oluşturmaktadır.

Taha Abdurrahman, tıpkı şehâdet kavramında olduğu gibi söz eylem teorisinin zeminini oluşturan bu epistemolojik alanı da iletişim modelinde bir enstrüman olarak kullanmaktadır. Bu epistemolojik alan, geleneksel şiir ve kelâmu'l-Arab șevâhidini içermenin yanı sıra, nahiv, belagat, sünnet-i nebeviyye alanlarını referans bilgi olarak görmekte, felsefe ve mantık gibi alanları ise transfer bilgi șeklinde içermektedir.

Taha Abdurrahman'ın söz eylem teorisinde temel üç alan, inanç (akide), dil (luga) ve bilgi (ma'rifet) alanlarıdır. Bu bağlamda Taha Abdurrahman'ın, Habermas'a itiraz noktası șehâdet ve haberin, dolayısıyla metafizik bilginin, Habermas tarafindan dikkate alınmaması ve salt istidlâl kurallarına teslim olunmasıdır. Taha Abdurrahman entelektüelleșmiş bir seviyedeki toplumun veya kendi 
tanımlamasıyla mütefakkih toplumun, bilimsel ve kültürel bir pragmatiğe ve kolektif zemine dayanması gerektiğini ifade etmenin yanında, kodları şehâdete uzanan bir epistemolojik modeli de öngörmektedir. Müzakere etiği, rasyonalizmin bir modelini oluşturmaktadır. Taha Abdurrahman'ın müzakere etiğine yönelmesinin nedeni, bu anlayıșın, değerleri nötralize eden objektif eğilimli bilimsel pozitivizmin sunduğu modelden farklı olmasıdır. Aynı zamanda Taha Abdurrahman açısından müzakere etiği, İslam'ın karşı olduğu “araçsal akılcılık (instrumental rationalism)” ve ondan kaynaklanan kavrayış tarzından da başka bir şeydir.

Taha Abdurrahman, ideal bir iletişim topluluğu arayıșı içindedir. Bu arayışında Taha Abdurrahman, Habermas gibi toplumu asıl, devleti fer olarak görmektedir. Ne var ki Taha Abdurrahman açısından ideal topluluk, dinî entelektüelleșmenin ifadesi olan tefakkuha bağlı bir epistemolojik difüzyondan ya da başka bir deyișle bilginin kapsamlı ve sistematik yaygınlık kazanmasından beslenir. Taha Abdurrahman'ın șehâdete dayalı iletişim tezi, akıl-nakil karşıtlığını kabul etmemekte ve akla karşılık, haberi alternatif bir unsur olarak değerlendirmemektedir. Bilakis her iki kavram alanı birbirini tamamlamaktadır. Bu doğrultuda Taha Abdurrahman'ın "şehâdet iletişimi tezi", şehâdet ve istidlâl kavramları arasında eşleşmeyi gerektirmektedir.

Anahtar Kelimeler: İslam Felsefesi, Taha Abdurrahman, Müzakere Etiği, Șehâdet, I'timâniyye, Tedâvuliyye.

On the Possibility of an Islamic Negotiation Ethics: Taha Abderrahmane's Theory of Communication Based on Testimony

\section{Summary}

Taha Abderrahmane is one of the important philosophers alive today in the Arab-Islamic world. With his theo-political writings he suggested "a deliberative model of political communication and an Islamic media theory in a physical and metaphysical unity", he constructed a holistic and versatile Islamic methodology in his works. This article focuses on Taha Abderrahmane's theory -ethical in one aspect and theo-political in the other- of communication and media based on testimony. According to Taha Abderrahmane, human communication is human and collective in one aspect and divine and conscientious in the other as a structure based on metaphysical dimension. This communication network, which requires physical and metaphysical integrity in terms of its references and reaches bazm-i alast (pre-eternal covenant), goes beyond mere inference. Thus, he employs the concepts of inference and witnessing in a balanced way in the field of communication and thus he creates a new negotiation ethics, communication model and an Islamic media theory. In the final analysis, this theory emphasizes that the concepts of conscience, burhan and power should be handled with an integrative understanding. Thus, it is predicted that all human relations will form a homogeneous structure in ethical, aesthetic and epistemological dimensions.

In general, religious epistemology has been seen to be neutralized in the field of media as an instrument of democracy and in some communication theories about the concept of deliberative democracy developed by libertarian theorists. One of these theories is Habermas's theory of communication, which Taha Abderrahmane made the subject of examination and comparison due to its emphasis on the collective nature of the negotiation. Indeed, indifference towards religion is a frequent occurrence in civil libertarian interpretations of democracy that have evolved into deliberative democracy, such as that of Jürgen Habermas. However, in deliberative democracy, nonstate negotiation areas are seen as a communication field. In addition, elements such as media, social media tools and associations are considered as a stakeholder of social communication, similar to the parliament, which is the official negotiating body of the state. On the other hand, indifference to the phenomenon of religion creates a paradoxical situation.

To establish an Islamic communication model and media theory, Taha Abderrahmane has benefited greatly from Jürgen Habermas's communicative action theory, one of the important representatives of negotiation democracy, but he also made serious criticism of this theory. The hadith of qurb alnawāfil, which adds a mystical aura to Taha Abderrahmane's theory, is a holy hadith, states that the servant, who is attached to Allah with submission and sincerity, will feel the grace and protection of Allah at any moment. This hadīth is mostly accepted in șüfi circles.

Taha Abderrahmane takes the Islamic knowledge base as a reference and works on the production of Islamic thought through historical memory. However, he did not regard this accumulation as a field based solely on collective and human consensus in this method. Rather, Taha Abderrahmane relied on the metaphysical memory in which man carried his memory in his own depth. Therefore, the 
knowledge production and communication processes of the Islamic society are also related to the concept of witnessing, which contains strong references to the conscientious dimension, which cannot be based solely on argumentation. One of the most important aspects guiding Taha Abderrahmane's works is word-action theory, based on a linguistic paradigm. Although Abderrahmane has taken Western sources as reference in many ways with this theory, he constructs a pragmatic approach quite different from the Western one. He built a holistic and versatile Islamic methodology in his works. It constitutes a world of thought in the axis of i'timanniyya (divine contract and trust paradigm) and tadāwuliyya (pragmatic-word-action theory). Like the concept of witnessing, Taha Abderrahmane used this epistemological field, which forms the basis of the word-action theory, as an instrument in his communication model. This epistemological field includes the testimony of traditional Arabic poetry and literature and also accepted the fields of 'ilm al-nahw, balāga and sunna as reference information. This epistemological field includes areas such as philosophy and logic as transfer knowledge.

The three basic fields in Taha Abderrahmane's theory are 'akìda (creed), lugia (language) and ma'rifa (knowledge) fields. In this context, the point of objection of Taha Abderrahmane to Habermas is that witnessing and metaphysical knowledge are ignored by Habermas and surrendered to the rules of bringing only evidence. Taha Abderrahmane states that society should be based on a scientific and cultural pragmatic and collective ground at a level that has evolved into an intellectual situation. Taha Abderrahmane also envisioned an epistemological model whose codes stretch back to witness. Negotiation ethics constitute a model of rationalism. The reason why Taha Abderrahmane gravitates towards the ethics of negotiation is this understanding differs from the model offered by the objectively oriented scientific positivism that neutralizes values. At the same time, the ethics of negotiation is different from the instrumental rationality against which Islam is opposed and the style of conception stemming from it.

Taha Abderrahmane is in search of an ideal communication community. In this pursuit, Taha Abderrahmane regards the society as the main and the state as the second degree, like Habermas. However, in terms of Taha Abderrahmane, an ideal community feeds on an epistemological diffusion of knowledge in fikh, which is the expression of religious intellectualization, or in other words, the extensive and systematic dissemination of knowledge. Taha Abderrahmane's based on testimony communication thesis doesn't accept the opposition of 'akl-nakl. In addition, he doesn't consider information as an alternative element in the face of reason. On the contrary, both concept areas complement each other. Accordingly, Taha Abderrahmane's "witness communication thesis" requires matching between the concepts of witnessing and inference.

Keywords: Islamic Philosophy, Taha Abderrahmane, Argument Ethics, Shahāda, I'timāniyya, Tadāwuliyya (Speech Act Theory).

\section{Giriș}

Günümüzde yoğun bir iletişim bombardımanı altındaki insanlık, eskiye göre çok daha fazla bir "medya teorisi" ve "medya etiğine" ihtiyaç duymaktadır. Kur'ân-ı Kerîm ve sünnet-i nebeviyyenin, bu etiğin oluşturulmasında sağlayacağı katkı ve dinamizm inkâr edilemez. Bu doğrultuda iletişimi, mekanik bir devinim olarak görmek yerine, bilgi aktarımı ile belli değerlerin ve erdemlerin akışını sağlayan bir sistem olarak değerlendirmek gerekmektedir. Endüstri toplumlarında giderek yalnızlaşan insanların birbirlerine sımsıkı bağlanmalarını, ortak kültür ve zengin bilgi temelinde birleşmelerini sağlayacak olan unsurların başında inanç, dürüstlük, ahlâk ve hoşgörü çerçevesinde işleyen müzakereye açılk bir toplum ve bir medya inşası gelmektedir. Dolayısıyla Taha Abdurrahman'a göre, müşterek bir ethostan sıyrılmayı öngören agonistik siyasetin iletişim modelleri, -Chantal Mouffe'un Carl Schmitt'e atıfla ifade ettiği gibi-kendi içerisinde liberal demokrasi terkibindeki ilk kavramın bireysel özgürlükçülüğü, ikinci kavramın kolektif uzlaşıyı gerektirmesi 
bağlamında bir paradoksa sürüklenir (Mouffe, 2015, 21). Bu bağlamda Taha Abdurrahman, tarihin dıșında gerçekleșmiş Elest Bezmi'ndeki metafizik şehâdeti referans almak suretiyle, "din" kavramını "siyaset ve kamu yönetimi stratejisi”nden soyutlanmaz biçimde bütünlükçü bir zemine oturtmaktadır. Bunun yanında o, kamusal alanda müzakere ve iletişim olgusunu, insanın Allah ile kurduğu şehâdete dayalı bir iletişime dayandırmak suretiyle inanç, ahlâk ve eylem alanlarını birleştirmektedir.

Bu itibarla Taha Abdurrahman'a göre, beşerî iletişim, metafizik boyutu esas alan bir yapı olarak, bir yönüyle beșerî ve kolektif, diğer yönüyle, ilahî ve vicdanîdir. Referansları bakımından fizik ve metafizik bütünlüğü gerektiren ve Elest Bezmi'ne ulaşan bu iletişim ağı, Taha Abdurrahman'a göre salt istidlâlin ötesine geçmekte, böylece o, iletişim alanında istidlâl ve şehâdet kavramlarını dengeli biçimde istihdam etmek suretiyle yeni bir müzakere etiği, iletişim modeli ve İslâmî bir medya teorisi oluşturmaktadır. Son tahlilde bu teori, vicdan, burhan ve sultan (iktidar) kavramlarının bütünlükçü bir anlayışla ele alınması gerektiğini vurgulamaktadır. Böylece tüm beşerî ilişkilerin etik, estetik ve epistemolojik boyutta homojen bir yapı oluşturması öngörülmektedir (Abdurrahman, 2012a, 133). Taha Abdurrahman, bu noktada fizikî ve metafizik boyutların birliği ilkesinden hareket etmekte ve -metafizik âlemi kendisine referans alan bir dünya arayışı içerisindemetafizik değerlerin arzî ya da seküler boyuta aktarılmasını ifade eden "teşhîd" kavramını gündeme getirmektedir. Son tahlilde o, teşhîd; şehâdet, şuhûd, işhâd, müşahede ve istişhâd gibi aynı kökten türemiş diğer kavramlarla birbirini tamamlayan ve mekanik argümantasyonun ötesinde, insanın tüm benliğiyle iman ettiği doğruluğa matuf bir semantik daire oluşturmaktadır. 0 , istidlâlin, mutlak hakikate vurgusu olmayan iknâî bir yol olduğunu, oysaki şehâdetin, insanın adalet vasfi ile ilişkili olduğunu düşünmektedir (Abdurrahman, 2012a, 46, 47, 71, 208, 280-281).

Böylece insanın Allah'ın varlığı ve birliğine olan şehâdeti, onun aklî ve burhânî kavrayışının ve vahyin yönlendirmesinin yanında bizatihi ruhuna ve zihin kodlarına ezelde yerleştirilmiş bir hakikat olarak bulunmaktadır. Söz konusu şehâdet kavramı, bir taraftan Allah ile insan arasında a-historik bir iletişim olgusunu gündeme getirmektedir. Diğer taraftan ise bu kelimeden türetilmiş işhâd [şahit tutma] kavramı, eyleyen bir insan olarak kulun, Allah'ın varlığına olan şehâdetinde gerek Allah'ı gerekse de Elest Bezmi'ndeki tüm diğer ruhları şahit tutmak suretiyle söz konusu tanıklığı hem kolektif bir şahitlik hem de metafizik ve derunî bir iletişim boyutuna taşımaktadır. Nihayetinde beșerin Hakk'a ve hakikate olan şehâdeti, şuhûd âlemindeki metafizik iletişim düzeyinden evirilerek, şehâdet âlemi olarak nitelenen bu dünyadaki beşerî alana aktarılmaktadır.

Taha Abdurrahman'a göre metafizik bir alana yaslanan ve bilahare insanın ruhuna kodlanmış bulunan ilk șehâdet, insanın doğru düşünmesini sağlamaya yönelik bir matriks özelliği taşımaktadır. İlahî bir potansiyel ve ruha yerleștirilmiş metafizik bir hatıra olarak bu enerji ve güç alanı, kolektiflik vasfını, ötekini şahit tutma [işhâd] hususiyetinden aldığı kadar, insanî varlığın çok katmanlı yapısına da borçludur. Bu çerçevede Taha Abdurrahman, kendi yorum yöntemi içinde İbrahim Peygamber'e atıfla bir tek insanın dahi ümmet ya da bir toplumsal yapı modeli ol- 
duğunu ifade eden Kur'ân-ı Kerîm ayeti ekseninde (İbrahim 16/120), iletişimin temelini olușturan kolektif yapının bir tek insanın içyapısında dahi bulunduğunu söylemektedir. Ne var ki bu yapı, Freudyen referansları olan psikanalizin aksine, salt fiziksel değil, fizik ve metafizik bir bütünlük arz etmektedir. Bu itibarla insanın varlığını, "o/id", "süper ego" ve "ego" katmanları şeklinde ele alan Freudyen yaklaşım, eksik ve hatalıdır (Abdurrahman, 2012a, 143).

Gerçekte psikanaliz, psikolojik rahatsızlıklarda, ma'şerî vicdan ve etik değerler ile kişinin kendi benliği arasında yüzeysel bir denge sağlama yoluna gitmektedir. Ne var ki psikanaliz, son tahlilde psikolojik rahatsızlığa maruz kişinin ruhundaki örselenmeye yönelik bir operasyona girişmeden, hastanın kamusal alandaki olası egemenliğini ya da tutsaklığını açığa vuran bastırılmış duygularını ona hissettirmeye çalışmakla yetinmektedir. Dolayısıyla psikanaliz, hastayı, ruhunu kasıp kavuran sıkıntılarından tamamen kurtarmayı amaçlamamaktadır. Son kertede bir iletişim modeli olarak psikanalizin yaptığı, sadece hastanın bilinci ile bilinçaltındaki çatışma vasıtalarını ortadan kaldırmaktan ibarettir. Böylece hasta, Hitler gibi ceberut biri de olsa iç dünyası ile dış dünya arasında bir ahenk yakalandığı andan itibaren problem ya marazî özelliğini yitirmekte ya da müdahalede çok geç kalınmış bir travma hâlinde bir yerlerde patlamaktadır. Ayrıca psikanaliz, Sigmund Freud'un temellerini attığı andan itibaren "libido" kavramına özel bir değer atfetmiştir ki neredeyse insanın, bunu, hayatında bütünüyle kendisine referans aldığı bir kural hâline getirdiği düşünülmüştür. Dolayısıyla Freudyen yaklaşım bir iletişim kanalı olarak beşeriyete mutluluk vaadini gerçekleştirmekten çok, insanî iletişimin önünde ciddi bir barikat olarak durmaktadır (Abdurrahman, 2012a, 261262).

İnsanlık bu durumda psikolojik alandan, beşerî iletişimde ikinci bir alan olarak kamusal alana yönelmiş ve demokratik ya da siyasî müzakere kavramını geliştirmenin peşine düşmüștür. Ne var ki siyaset alanı, nefsin, sahiplenme ve aidiyet duygusunun bir ifadesi olan "nisbet" kavramı ile maluldür. Nisbet olgusu doğrultusunda insan, eşyayı kendi zatına nisbet eden nefsanî eğilimini vasıta yaparak, metafizik âlemin üst değerlerini fizikî âleme transfer ettiğini düşünmekte ve fiziksel olgulara kutsallık atfedebilmektedir. Taha Abdurrahman bu eğilimi, teşhîd kavramının tam zıddı olarak tagyîb adıyla anmaktadır (Abdurrahman, 2012a, 45, 46). Fizikî âleme metafizik değer atfı şeklindeki tagyîb olgusu, insanın, kamu yönetimi ve siyaset stratejisini [tedbîr], yaratıcısının idare ve müdahalesinden bağımsız görmesi ve Rabbine kul olmak ve dinî ve taabbüdî hayatını buna göre tesis etmek [taabbüd] yerine, kendi benliğine ve varlığına tapınmayı tercih etmesi şeklinde belirginleşmektedir. Aslında Taha Abdurrahman, siyasal yönetim şekilleri içinde en makul sistem olarak gördüğü demokrasinin uygulamalarından doğan farklılıkların idrakindedir. Çoğu defa demokrasilerde siyasî tanımlar, "adalet", "özgürlük" ve "eşitlik" gibi dinî tanımlardan iktibas edilerek ortaya konulmaktadır. Diğer bir yol ise siyasal alanda içerik aynı kalmasına rağmen, dinî terimde bir ad değişikliğine gidilmesidir. Bu şekilde "tolerans", "ihtiram"; "ötekini kabul etme", "komşu hakkına riayet" ve "yasalar önünde eşitlik", "dinin bütün insanlara eşit muamele etmesi" gibi olgulara kıyasla oluşturulmuştur. Aslında siyasî kavramların, -agonistik 
siyasetteki müzakere sürecinde dinî birikime kayıtsız kalınmasına karşın- gerçekte meșruiyetini, dinî epistemolojiden alması gerektiği söylenebilir. Bu doğrultuda siyasî tanımlar, siyasî pratiğe özgü bir metafizikleştirme sürecine tâbi kılınmıştır. 0 hâlde söz konusu siyasî kavramların meşruiyeti, metafizikleştirilmiş bir meşruiyettir. Metafizikleștirilmiş meşruiyet, aslında dinî meşruiyet ile birebir aynı özelliktedir (Abdurrahman, 2012a, 152). Bu durumda dinin verili bilgi alanının müzakerelerde ve beșerî iletişimde devre dışı bırakılması ve dinî epistemolojinin, seküler planda bir referans değeri taşımadığının düşünülmesi önemli bir iletişim hatasıdır.

Burada kastedilen, müzakere ve argümantasyonda tarafların dinî ve metafizik meşruiyet üzerinden hareket etmeleri değildir. Bilakis temel referanslarını Fransız düşünür Jean Jacques Rousseau'nun Toplum Sözleşmesi adlı meşhur kitabından alan "sivil din" kavramsallaştırması çerçevesinde seküler toplumların dini dışlayıcı tutumlarının gerçeklikten uzak oluşu ve dinî olgunun argümantasyonda devre dışı bırakılması iddiasının aslında modern seküler toplumların kuruluş şeması açısından ikircikli bir vaziyet arz etmesidir. Zira seküler toplum yapısında dinî kavramların bir analoji çerçevesinde dünyevî ve kamusal alana aktarıldığı görülür. Kamusal alanda bir taraftan ladinî bir tutum, diğer taraftan dinî kavram alanının seküler bir kavram alanı oluşturacak şekilde kullanımı yeterince paradokstur. Durum böyleyken, demokratik müzakerelerde dinî bağlamından koparılarak da olsa seküler bilincin ikamesinde istihdam edilmiş bu semantik örgünün, kamusal sferdeki söz konusu tüm varlığına rağmen din olgusunun yok sayılması paradoksu daha da derinleştirmektedir.

Taha Abdurrahman'ın sivil din olgusu çerçevesinde, dinî semantik alan ile seküler kamu alanı arasında kurulan analojiye dair verdiği örnekler ilgi çekicidir. $\mathrm{Bu}$ bağlamda George Washington Musa Aleyhisselâm'a benzetilir. Çünkü tıpkı Musa Aleyhisselâm'ın Firavun'un despot uygulamalarından halkını kurtarmak suretiyle ilâhî inayete mazhar olması gibi, George Washington da halkını İngiliz sömürgesinden kurtarmak suretiyle ilâhî inayete mazhar olmuştur. Benzer şekilde Abraham Lincoln de Yahudilere peygamber olarak gönderilen İsa Peygamber'e benzetilir. Zira o da bir ilâhî yazgı olarak İsa Peygamber'in kullar için hayatını feda etmesi gibi ilâhî takdir sonucu köleler için hayatını feda etmiştir. Sivil dinin şehitler listesine John F. Kennedy ve Martin Luther King de eklenebilir. Benzer şekilde tıpkı Yahudilik ve Hıristiyanlıkta olduğu gibi sivil dinin kutsal bir kitabının olduğu konusunda da hiçbir şüphe yoktur. Şöyleki "Bağımsızlık Bildirgesi" ve "Anayasa", onun kutsal kitabı niteliğindedir. Ayrıca sivil dinin, Washington Heykeli ve Lincoln Anıtı gibi birtakım tapınakları ve anıtları da olduğunu söylemek gerekir. Sivil din için vatan uğrunda canlarını feda eden vatandaşları tazim etmek ve minnettarlığın bir ifadesi olarak Gettysburg Ulusal Askerî Mezarlığı ve Meçhul Asker Anıtını da içine alan Arlington Askerî Mezarlığı gibi anıt mezarlar inşa edilmiştir. Son olarak sivil din için aynı şekilde Bağımsızlık Günü, Anma Günü (Memorial Day), Şükran Günü ve Gaziler Günü gibi kitlesel ritüeller ve bayramlar oluşturulmuştur." (Abdurrahman, 2012a, 228, 229).

Genel anlamda demokrasinin bir enstrümanı olan medya alanında ve -farklı versiyonları olmakla beraber- liberteryan teorisyenler tarafindan geliștirilen mü- 
zakereci demokrasi kavramı ile ilgili birtakım iletişim teorilerinde dinî epistemolojinin etkisiz hâle getirildiği görülmektedir. $\mathrm{Bu}$ teorilerden biri, Taha Abdurrahman'ın, müzakeredeki kolektiflik özelliğine vurgusu nedeniyle inceleme ve mukayese konusu yaptığı Habermas'ın iletişim teorisidir. Aslında dine kayıtsızlık, Jürgen Habermas'nki gibi demokrasinin müzakereci demokrasiye evirilmiş sivil liberteryan yorumlarında sıkça görülen bir durumdur. Oysaki müzakereci demokraside devlet dışı müzakere alanları, bir iletişim alanı olarak görülmekte, medya, sosyal medya araçları ve dernekler gibi unsurlar, devletin resmî müzakere organı parlamento ile benzer nitelikte, toplumsal iletişimin bir paydaşı olarak değerlendirilmektedir. Buna mukabil din olgusuna kayıtsız kalınması paradoksal bir durum oluşturmaktadır. "Söylemsel demokrasi", "diyalojik demokrasi" veya "müzakereci-diskürsif demokrasi" diye bilinen teorinin önde gelen temsilcilerinden biri sayılan meşhur Alman sosyolog ve filozof Jürgen Habermas, çatışmanın, "müzakere" olgusuna dönüşmesi gerektiğini düşünerek, bütün bakışını müzakere teorisine (iletişimsel eylem kuramına) çevirmiştir. Söz konusu kuramsal yaklaşım, Habermas'ın "söylem etiği" ve "iletişimsel akıl" olarak adlandırdığı rasyonelleşme olgusu üzerine temellendirilmiștir (Habermas, 2019b, 45, 69). Ne var ki ifade edildiği üzere bu teori, din olgusunun kavramsal üretimini, üstü kapalı biçimde müzakere ve iletişimin bir referansı olarak görmemek konusunda bir direnç içindedir. Tam bu noktada Taha Abdurrahman, teşhîdin gerçekleștirilmesi, yani "metafizik değerlerden doğan ahlâkî erdemlerin bu dünyada egemen kılınması" için insanın, bireysel planda, kendi fitratına yerleștirilmiş olan ilahî kodlardan yararlanmasını önermektedir. Ona göre insan, fitrî hafızasını -ruh, akıl ve beden bütünlüğü içerisinde- canlandırmalıdır. Bu doğrultuda Taha Abdurrahman, aklî istidlâli ya da başka bir deyişle argümantasyonu dışlamadan bunun hemen yanına, fitrat ve hafızadan beslenen ve zihnin boş bir levha ya da başka bir deyişle tabula-rasa olmadığının bir ifadesi olan șehâdet kavramını yerleștirmektedir. Taha Abdurrahman, toplumsal planda ve kolektif müzakere düzleminde istidlâl kadar, șehâdetin de önemli olduğunu hatırlatarak, diyalojik demokrasiye karşı modern agonistik (çatışmacı) siyaset teorileri ile eleștirel bir bağ kurmaktadır (Abdurrahman, 2012a, 159, 160). 0 , bu suretle daha genel manada benimsediği emanet paradigmasına bağlı farklı bir iletişim ve medya modeli önermektedir.

Taha Abdurrahman'ın paradigmasının şehâdet kavramını ve Elest Bezmi diye bilinen ilk şehâdeti referans almasının nedenleri arasında insan zihninin birtakım bilgilerle mücehhez olması ve ilâhî isim teorisi gibi kabulleri bulunmaktadır (Abdurrahman, 2017, 1/28, 29). Bu çerçevede Taha Abdurrahman'ın, İslâmî bir iletişim modeli kurduğu iddiasıly sunduğu paradigma aslında i'timâniyye (trustsheep paradigm) adındaki daha büyük bir paradigmanın yalnızca bileșenlerinden biridir. Bu paradigma etik, epistemolojik ve politik parametreleri beraberce içeren sistematik bir bakıș sunmaktadır. Kușkusuz bu makalenin konusunu teșkil eden Taha Abdurrahman'ın iletișim ve medya teorisi ve onun müzakere etiğine ilişkin görüşleri, sadece Habermas'ın paradigmasına bağlanamaz. Buna mukabil Abdurrahman'ın iletişim ve medya teorisinin daha net anlaşılabilmesi büyük ölçüde onun, Habermas'ınki gibi Batılı modern müzakere ve iletişim teorilerine yönelik 
eleştirilerini anlamaktan geçmektedir.

\section{Taha Abdurrahman'ın, Jürgen Habermas'ı Eleştirileri Bağlamında İletişimde, İstidlal ve Şehâdet Kavramlarının Birleştirilmesi Projesi}

Taha Abdurrahman, İslâmî bir iletişim modeli ve medya teorisi kurmak için müzakere demokrasisinin önemli temsilcilerinden Jürgen Habermas'ın iletişimsel eylem teorisinden oldukça yararlanmış, fakat aynı zamanda bu teoriye yönelik ciddi eleştirilerde bulunmuştur. Kabaca biri geniş ölçüde John Rawls, diğeri de Jürgen Habermas tarafından etkilenen iki ana okulda tasnif edilebilecek olan müzakereci demokrasinin çok sayıda versiyonu söz konusudur. Belirli bir tür Modus-Vivendi tipini eleştiren müzakereci demokrasi modeline göre, bir yönetim sürecinde kolektif karar alma süreçleri açısından meşruluk ve rasyonelliğe erişilmesi, öngörülen yönetim biçiminde herkesin ortak çlkarına olduğu kabul edilen kurumların, özgür ve eşit bireyler arasında rasyonel ve adil bir şekilde yürütülen "kolektif müzakere" süreçlerine bağlıdır (Mouffe, 2015, 89, 95). Gerçekte Jürgen Habermas'ın paradigması, Kant ve Hegel'in teorilerine kadar uzanmaktadır. Daha doğru bir tanımlama ile Habermas, fenomenolojik duygunun sınırlarında gerçekleşen transandantal varsayımlar üzerine ikame ettiği bir ahlâkî bakış ortaya koymak için Hegel'in Kant'a yönelttiği eleştirilerden yararlanmıştır (Abdurrahman, 2012a, 98). Habermas'ı kuramı, ahlâkî kuralları ifade etmek üzere deontolojik, epistemolojik, formel ve evrensel özellikler olmak üzere dört öbek üzerinden bir etik geliştirmeye odaklanmıştır (Mellouk, 2018, 105). Habermas'ın demokrasi ve müzakere anlayışı, insan aklının post-metafizik kavramına dayanmaktadır (Yükselbaba, 2008, 172173). Nihayetinde Habermas, paradigmatik olarak sivil itaatsizlik kavramı üzerinden gitmekte, ne var ki bunun şiddete dayalı ya da trafiğin engellenmesi, girişlerin bloke edilmesi ve resmî kurumların ve devlet memurlarının görevlerine engel olunması gibi şiddet çağrışımı içeren türden eylemler olmaması gerektiğini ifade etmekte ve iletişimsel eylem teorisinin temelini oluşturan ikna stratejisini önermektedir (Dworkin, 2018, 154). Bu strateji, barışçll, vicdanî ve tüm sosyal tabakaları içine alan kolektif bir dayanışmaya işaret etmektedir (Habermas, 2018d, 128129).

Gerek Habermas'ın gerekse de Taha Abdurrahman'ın teorileri, araçsal aklın eleştirisi, devlet dışı kamusal mekân olgusu, müzakere kavramı, niyet ve özgürlük gibi birçok hususta birbiriyle uyuşmaktadır. Bununla beraber Taha Abdurrahman, Habermas'ın iletişimsel eylem teorisini, başka bir deyişle "argümantasyon-istidlâl iletişimi [tevâsülüll-istidlâl]" tezini, bu teorinin birçok parametresi açısından eleştiriye tâbi tutmaktadır. Bu çerçevede Taha Abdurrahman, Elest Bezmi'ndeki iletişime dayandırdığı i'timâniyye (emanet paradigması) ve beşerî tavır ve praksis anlayışı doğrultusunda, hâkim rengini naslardan alan, fakat bir yönü ile de senkretik referans ağına sahip -kendi deyimiyle- bir şehâdet iletişimi (tevâsülü'ş-şehâdet) modeli geliştirmiş̧ir. Taha Abdurrahman'ın paradigması, -Habermas'ın müzakere modelinin aksine-, müzakerede bir iddianın, hem istidlâlî yoldan, yani argümanlarla desteklenmesini gerektirmekte hem de müzakerecinin, iddiasına ve deliline şehâdette bulunmasını şart koşmaktadır (Abdurrahman, 2012a, 153, 164, 165). 
Hâlbuki Habermas'ın merkezî kavramı, [bir tür istidlâl mekanizması olan] argümantasyon mantığıdır. Argümantasyon mantığı, -formel mantıkta olduğu gibi anlamsal birimler arasındaki "tümdengelim"li bağlantılarla değil-, argümanların oluşturduğu pragmatik birimler (söz eylemleri) arasındaki içsel ilişkiler ve tutarlılıkla bağlantılıdır. Aslında bu yaklaşım, [kapsamında din de bulunmak üzere her türlü] mutlaklığın yıkımıdır (Yıldırım, 2006, 260). Zira geleneksel mantık, otonom sonuçlar doğuran mutlakçılığı besleyen bir sistemdir. Müzakereci söylem ise dilin ve kültürün ayrıştırdığı insan davranışlarını, ahlâkî bir potada [nesnelleştirilmiş bir normatif anlayış ideali içerisinde] salt argümantasyon kuralları üzerinden uzlaştırmaya koyulmaktadır (Habermas, 2019b, 755, 762, 765, 779). Düşünce alanında Habermas'a yönelik itirazlar, farklı boyutlarda dile getirilmiştir. Örneğin, Wittgenstein'ın "neo-pragmatik" okunuşunu öneren Richard Rorty gerek Apel gerekse de Habermas'a itiraz ederek, dil felsefesinden evrenselci bir ahlâk felsefesi türetmenin imkânsız olduğunu ileri sürmektedir (Mouffe, 2015, 72).

Habermas'ın iletişimsel eylem kavramının çıkış noktası, Marksist emek kavramının toplumsal olarak tıkanmasıdır. Bu ise tarihsel materyalizmin yerine Habermas açısından iletişimsel eylem olgusunu gerekli kılmaktadır. "Diğer yandan bu, artık Marksizm'in araçsal akıl ile tözsel akıl arasındaki ayrımı yerine araçsal akıl ve iletişimsel akıl kavramları çerçevesinden yeni bir akılcılığın inşasıdır" (Specter, 2012, 162). Habermas'in paradigmasının, Kant, Marx, Hegel ve Weber'e uzanan toplumsal teorik referanslarının yanında iletişim kavramı noktasında konuşmanın evrensel geçerlilik temelini oluşturmak üzere dilbilimden ve bilhassa Wittgenstein, Sellars, Austin ve Searl'in dilbilimsel kuramlarına dayandığı söylenmelidir. Bu Habermas'ın düşünsel olarak dilbilimsel bir dönüş, daha doğru bir tanımlama ile antropolojik bir dönüş yaşadığının göstergesidir (Specter, 2012, 164).

Habermas'a göre, dil (aktarılmış simgeler), emek (çalışma-üretici güçler) ve törel iliş̧iler (aile ve karşılıklılık esasına dayalı eylem) diyalektiği, nesneyi ve özneyi uzlaştırır. Habermas'ın bu değerlendirmesi gerek diyalektik kavramsallaştırması açısından gerekse de gayriyet kavramı açısından Hegel'e uzanır. Habermas, öz bilinç teorisini Hegel, Fichte ve Kant dolayımında tartışır (Habermas, 2019d, 9, 12, 13). Özellikle formel mantık ve dil çalışmalarının Taha Abdurrahman açısından da önemini kabul etmek gerekmektedir. Ne var ki Taha Abdurrahman lengüistik bir zemin üzerinden ahlâk inşa etmek yerine bu konuda şehâdet kavramsallaştırması ile metafizik bir eksen oluşturmak istemekte ve bu eksen üzerinden yürüyerek ruha yerleștirildiğini düşündüğü doğruluk kıstası ile dilin yanıltıcı unsurlarından siyrılmak istemektedir. Bu doğrultuda o, "Ey iman edenler! Ĕger Allah'a karşsl gelmekten sakınırsanız; O, size iyiyi kötüden ayırt edecek bir anlayış verir." (Kur'ân-ı Kerîm Meâli, 2009, el-Enfâl 8/29) ayeti gibi İslam'ın nassî boyutuna kuvvetli atıflarda bulunmakta, bu çerçevede özellikle nevâfil hadisi diye bilinen hadisi esas alarak, fitrata dayalı bir praksis oluşturmaya çalışmaktadır (Abdurrahman, 2012a, 287).

Taha Abdurrahman'ın teorisine tasavvufî bir neşve katan nevâfil hadisi, Allah'a teslimiyet ve samimi bir taat ile bağlanmış olan kulun her an yanında Allah'ın inayet ve himayesini hissedeceğini ifade eden kudsî bir hadistir ve hadis daha çok 
tasavvuf çevrelerinde kabul görmektedir. Söz konusu hadiste “(...) Kulum bana nafile ibadetlerle yaklaşmaya devam eder, sonunda sevgime erer. Onu bir sevdim mi artık ben onun işiten kulağı, gören gözü, tutan eli ve yürüyen ayağı olurum. Benden bir şey isteyince ona mutlaka veririm, benim onu korumamı isterse onu mutlaka korurum. (...)" ifadeleri yer almaktadır (Buhârî, "Rikâk", 38). Öyle görünüyor ki Taha Abdurrahman açısından bu hadis, insanın (fenâ hâli içerisinde kendi beşerî şuhûdundan vazgeçmek suretiyle kurbiyet elde ettiği Allah'ın lütfu olan ruhanî müşahedesi (şuhûd-ı rûhî) sayesinde ilahî emre muhatap olmasına bir atıf niteliğindedir. Ne var ki Taha Abdurrahman kendi teorisi açısından böylesi bir soyut duruma atıfta bulunsa da dilsel paradigmayı ve rasyonel mantığı bütünüyle bir kenara koymamaktadır. Hatta o, Arap nahvini ve Aristo mantığını tarih içerisinde Sîrâfî ve Mettâ b. Yunus'unki gibi çatışmacı bir refleksle de ele almamaktadır. Taha Abdurrahman için dil referans bilgi (me'sûl) iken Yunan felsefesi ve Aristo mantı̆̆ transfer bilgi (menkûl) olarak İslam düşüncesinde bir değer ifadesidir (Abdurrahman, 2012b, 297).

Aslında Taha Abdurrahman'ın bu yaklaşımı, tarihsel olarak mütekellim fıkıh ekolünün holistik ya da başka bir deyişle bütüncül yaklaşımı ile benzerlik göstermektedir. $\mathrm{Bu}$, mutlak kaziyeleri ve matematiksel-mekanik formel kıyası ile Aristo mantığının, -değişkenlere, görece kapalı bir denetim mekanizması olarak- fıkhın ve şer'î ilimlerin içerisine yerleştirilmesinden ibarettir. Bu çerçevede söz konusu âlimler, formel mantığı, fikıh, kelâm, cedel ve el-Arabiyye ile bütünleștirirken, onu mekanik bir sistem olarak görmüşlerdir. Ekolün önemli şârihlerinden Seyfüddîn el-Âmidî'nin (öl. 631/1233) el-İhkâm fî usûli'l-ahkâm adlı eseri, söz konusu yaklaşımın tipik bir örneğidir (Âmidî, 1402, 1/9, 13, 35). Bu doğrultuda Taha Abdurrahman, onlar gibi holistik bir tutum benimsemiş olsa da bilgiyi denetleme mekanizması olarak formel mantık yerine, gerek Elest Bezmi ile ruhta kodlanmış olduğunu kabul ettiği doğruluk kıstasını, gerekse de bilimsel ve kültürel birikime dayalı pragmatiği esas almıştır. Elbette Taha Abdurrahman açısından bu pragmatik, İslâm kültür ve medeniyetinin nassa dayalı ilmî ve dilsel birikiminden ibarettir. Zira onun ifadesiyle rasyonel mantık, tecrîdî ve soyutken; [bir kültürel form olarak] Arapça istimâl odaklıdır (Abdurrahman, 1994, 318).

\section{Taha Abdurrahman'ın Ahlâk Anlayışının, Habermas'ın Paradigma- sı Bağlamında Modern Liberal Söylemdeki Yeri}

John Rawls gibi adaletin iyilik karşısında kavramsal önceliğinin önemine işaret eden Habermas, geleneksel dinsel öğretilerin iyiliği adalete öncelediklerinden yakınmaktadır. Ona göre, adalet ve iyilik kavramları liberal demokrasilerde paradoksal bir sembiyoz oluşturmadan, normatif gerekçelerle asimetrik biçimde çaprazlanmış olarak kalabilir. Oysaki dindar bir kişinin mutlak hakikat inancına sahip olması onun iyiliği adaletten öncelemesini gerektirir ki bu toplumsal uzlaşı açısından sorunlu bir durumdur (Habermas, 2019a, 274). Oysaki İslam düşüncesinde farklı spekülasyonlar olmakla birlikte adalet, temel bir kavram olarak kavramsal piramidin en tepesindedir (Ebü'l-Bekâ el-Kefevî, ty, 1/53). İslam mezhepleri arasında usulü hamse metodolojisi ekseninde Mutezile'nin adalet kavramını hi- 
yerarşik olarak iyilik ve iyiliği emretme olgusunun üstünde konumlandırdığı bilinmektedir. Taha Abdurrahman da adaleti tüm kavramlara öncelemektedir. Adalet ilkesi ve ahlâk kurallarını ise iyilik ilkesi organize eder (Abdurrahman, 2012a, 72).

Habermas'a göre dinî tutumun bu olumsuzluklarına rağmen sekülerleşen toplumda eşitlikçi ilke gereği dinin canlılığını koruması ve dindarların müzakere süreçlerinde özellikle mensubu oldukları dinî paradigmanın etik değerler sistemi ile ilgili olumlu olabilecek katkıları itibarıyla iştirakleri beklenir. Habermas açısından seküler epistemoloji, dine akıl dışı olmayan bir statü atfederse din akılcı sıfatını hak edebilir. Elbette eşit özgürlüklerin sağlanması, devlet gücünün sekülerleşmesini gerektirir. Ama seküler dünya görüşünün politik olarak aşırı genelleștirilmesini de yasaklar. Liberal politik kültür, dinî söylemin seküler söyleme tercüme edilmesine izin vermelidir. Zaten parlamento seküler bir süzgeçtir (Habermas, 2019a, 294-295). Bu ölçülerde yasama sürecinde dinî meşrulaştırmalara karşı hoşgörü, isabetli bir tavırdır. Liberal devlette sadece seküler gerekçelere önem verildiği göz önüne alınırsa bir inanca bağlı vatandaşlar dinî ve seküler kanaatler arasında bir tür denge, Robert Audin'in sözü ile "ilahî etik denge" kurmaya zorlanır. Unutmamak gerekir ki rekabet eden dinî inançlardan haklılaştırılmıș bir konsensüse erişilemez (Habermas, 2016, 2, 190, 191).

Günümüzde genel kabul görmüş değerlerin hızla çökmekte olan hiyerarşisine felsefî bir temel sağlayabilmek için geçmişteki nesnel akıl kuramlarını canlandırma yolunda genel bir eğilim vardır. Bu eğilim gerçekten de günümüze dek süregelmiştir. Sözde dinsel, yarı bilimsel ruh tedavileri, ruhçuluk, yıldız falı, yoga ve Budizm gibi eski felsefelerin ya da mistisizmin ucuz baskılarının yanı sıra klasik nesnelci felsefelerin, orta çağ ontolojilerinin popüler uygulamaları da modern kullanıma sunulmaktadır. Ne var ki nesnel akıldan öznel akla geçiş bir rastlantı değildir ve düşüncelerin gelişim süreci de herhangi bir anda keyfi olarak geri çevrilemez. Eğer aydınlanma biçimindeki öznel akıl, Batı kültürünün ayrılmaz bir parçası olan inançların felsefî temelini yok etmişse bunu bu temelin çok zayıf çıkmasından dolayı yapabilmiştir. Bu çerçevede Habermas, Yeni Thomacılık, Platon ya da Aristoteles'e bağlanarak felsefenin dünyayı bir bütün olarak kavrama yönündeki ontolojik iddiasını Horkheimer'e atıfla ister ön eleştirisel olarak isterse nesnel idealizm adına aklı, metafizik olarak yeniden yorumlamanın gereğine inanır (Habermas, 2019b, 487). Habermas, Cassirer ve Rickert'e atıfla dini mitolojiye indirgemekte ve mitos sanat ve din alanlarını nomolojik bir perspektife oturtmaktadır. Bu, bir yandan mutlak gerçeklikten düşünsel ve metodolojik olarak vazgeçmenin ve bunu skolastik düşünceye irca etmenin bir ifadesiyken diğer yandan normatif bir bilim kuramı inşasının temelini oluşturmaktadır (Habermas, 2018c, 99, 107, 109).

Habermas'ın tercüme kavramsallaştırmasının diğer eksenini dinî söylemin seküler söyleme tercümesi olgusu oluşturur. Habermas, Kant'ın dini, salt ahlâksal içeriğe indirgemesini ve bu suretle aşkınlığın yıkımını seküler dizge açısından olumlamaktadır. 0 , deontolojik ya da normatif etiğin, sonuçtan ziyade doğru eylem problemi üzerinde durmak suretiyle, teolojik etiği karşıt pozisyonda görmesini de bu doğal sürecin parçası olarak ele almaktadır (Habermas, 2019a, 206, 211). Habermas'a göre Katolik dünya imgesinin çöküşü ve çoğulcu topluma geçiş ile ah- 
lâkî ve aşkın tanrı düşüncesi kamusal alanda gerçekliğini yitirmiştir (Habermas, 2019c, 186). Habermas, bir kişinin saygiya değer ahlâkî özünü sadece ikinci kişiler karşısındaki edimsel tutumu noktasında değerlendirebileceğimizi ifade eder. Bu doğrultuda ancak en az iki kişi, bir şey hakkında birbirini anlamak/uzlaşmak için öznelerarası paylaşılan yaşam evreninin çerçevesinde, yani iletişimsel eylemde buluştuklarında, aktörler karşılıklı olarak birbirlerini sorumlu kişiler olarak tanıyabilir ve tanımalıdırlar. Ahlâkî kurallarda yazılı olan öznelerarası ilgiler nedeniyle, olumsuz veya olumlu haklar ve yükümlülükler, özel olarak ruhun kendi kendisiyle tek başına monoloğunda gerekçelendirilemeyeceği gibi aynı şekilde bunlar uygulanabilir bir norm olarak kabul edilemez (Habermas, 2020, 194-195). Habermas, müzakereyi salt aklî argümantasyona dayalı bir öznelerarası olgu olarak değerlendirdiği için ahlâkı da kolektif bir müzakerenin sonucunda ortaya koyulan kararlar muvacehesinde değerlendirmektedir. Bu anlayıș, onun, ahlâkı kolektif bir unsur olarak görmesine ve bireyin münferit ve öznel olarak ahlâka sahip olamayacağı düşüncesine götürmüştür. Halbuki İslâmî paradigma açısından Allah'ın ahlâkı ile ahlâklanma çerçevesinde ferdin izole bir şekilde de ahlâkîlik boyutu taşıması doğaldır. Taha Abdurrahman'ın değerlendirmesi ekseninde Kur'ânî referansa dayalı olarak tek bir kişi bir ümmettir ve o, psikanalizin aşan bir çeşitlilikte bâtınî katmanlara sahiptir. Diğer taraftan ilâhî isimlerin insan üzerinde tecellisi tanrısal ahlâkı insanda belirgin kılmaktadır. Dolayısıyla ahlâkî kurallar manzumesini müzakerenin haricî kolektivitesinde değil, beşerî fitratın bâtınî çoğulculuğunda aramak gerekir (Taha Abdurrahman, 2012a, 143, 258).

Karl Jaspers'in yaklaşımı ve kavramsallaştırmasıyla milattan önce 800-200 yılları arasındaki döneme tarihlenen Aksiyal Çağda ortaya çıktı̆̆ı iddia edilen peygamberli din öğretileri antik imparatorlukların bilişsel ufkunda yayılmıştı ve bu durum söz konusu imparatorlukların evrenselliği ile dinlerin dışlayıcı geçerlilik savı arasında tam bir uyumun neticesiydi. Habermas'a göre modernitenin hızla artan karmaşıklığında tek bir dinin dışlayıcı gerçeklik savını naif bir biçimde devam ettirmek mümkün değildir. Zira böylesi bir iddia bilișsel uyumsuzluklara neden olur. Çünkü çoğulcu toplumların karmaşık yaşam koşullarına, normatif olarak sadece -ister Katolik veya Protestan olsun, isterse Müslüman, Yahudi, Hindu, Budist, inançlı ya da inançsız- herkesin aynı ölçüde değerli olduğunu söyleyen katı bir evrenselcilik uyum gösterebilir. Aslında bu yaklaşım normatif özden yoksun bir Batı inşa etmektedir. Habermas, iletişimsel eylem paradigmasının temel parametreleri ile dinsel alanın -dışlayıcı geçerlilik savı ekseninde- epistemolojik bir paradoks oluşturacağı düşüncesindedir. Ne var ki yine de Habermas, Gadamer'e de atıfla başka evrenlere kapalı bir siyasî semantik alanın sorunlu olduğunu söylemekte ve iletişimin güçlünün asimilasyonuna bağlı olduğu takdirde şiddeti besleyeceğini düşünmektedir. Bunu ise 11 Eylül olayları ile Cihadist eylem stratejisi arasında bağ kurmak suretiyle örneklendirmektedir (Habermas, 2006, 15, 16, 23).

Habermas, bu süreçte hukukun da ahlâktan ayrıştırılmasından habersiz değildir. Onun kendi ifadeleriyle modern hukukî düzenler esas olarak sübjektif haklar üzerine inşa edilmişlerdir. Modern hukuk bu suretle geleneksel hukuk düzeninin aksine meşhur Hobbes prensibine geçerlilik kazandırmaktadır: Açık ve kati bir 
şekilde yasaklanmamış olan her şey caizdir. Böylelikle hukuk ve ahlâk birbirinden ayrılmaktadır (Habermas, 2018b, 152). Elbette Habermas açısından müzakerede, etik bir paradigmanın, akla uygun ve uzlașımsal bir tezahürü vardır ve müzakere nihayetinde komünikatif bir eylemdir. Burada eşitlikçilik ve hak kavramı ön plandadır. Zaten siyaset mekanizması da meşruiyetini iki şeyden, millî egemenlik ve insan hakları kavramlarından alır. Habermas'a göre Batıda insan hakları, adem-i merkezîleșme ile eşitlikçi bir hak kavramına evirilebilmiştir. İnsan hakları, moral olgular gibi önceden hazır, var olmuş değillerdir. Anayasa koyucu niteliğe sahip pratikler modelini bunu göz önünde bulundurarak anlamak gerekir. İnsan hakları birer kurgudur ve birer kurgu oldukları için haklar gibi siyasî mükellefiyeti olmayan bir konumu sürdüremezler. İnsan hakları sübjektif haklar oldukları için adlî kurallarla aynı tabiata sahiptirler ve yasama organlarınca pozitifleștirilmeye muhtaçtırlar (Habermas, 2018b, 154, 155, 156, 163).

Taha Abdurrahman açısından şehadet kavramı, Batı'nın adem-i merkezileşme ile elde ettiği hakların eşitlikçi biçimde dağılımını ifade eden ontolojik bir matrikstir. Bu hâliyle şehadet, sübjektiflikten çok, bir idealleştirmeden yola çımaktadır. Bu itibarla şehadet kolektif bir realizmin ifadesidir. Şehadet, ferdiyetçiliği de komunitaryen tutumu da ontolojik ve epistemolojik bir kolektivite potasında eritir. Üstelik ilahî emanet paradigması açısından bu, ahlâkî bir eylem alanı ya da başka bir ifadeyle aksiyolojik bir praksis de oluşturur. Aslında Habermas genel olarak Doğu'da hukuk ile etik arasında keskin bir ayırımın olmadığının farkındadır. 0 açıkça doğu toplumlarının geleneksel olarak haklar değil, vazifeler sayesinde bütünlük sağladığını, siyasî etiğin ise sübjektif hakları değil, sadece fertlere tanınan hakları bildiğini ifade eder (Habermas, 2018b, 165). Bu noktada Taha Abdurrahman'a göre Doğu'nun paternalist siyaseti savunması söylemi ile mesele kapatılamaz. 0, ahlâkın diğer sistemlerden, özellikle siyasetten ayrıştırılmasına yönelik ciddi eleştiriler yöneltir ve kavramsal analizlere girer. Arapçada almâniyye din ile siyasetin ayrıștırılmasını ifade eden bir sekülarizm kavramına denk düşerken, ilmâniyye din ile bilimin ayrıștırılması ifade eder. Taha Abdurrahman'ın icadı olan dehrâniyye kavramı ise din ile ahlâkın ayrıştırılması anlamına gelir ki bu, dünyevileşmedeki en büyük riski doğurur. Zira akıl kategorileri mücerred, müsedded ve müeyyed hiyerarşisine tabidir. Mücerred akıl, araçsal aklın karşılığıdır ve en düşük aklî düzeydir. Taha Abdurrahman araçsal akla karşı değildir. Ancak daha üst düzeydeki müeyyed aklın devre dışı bırakılmasının materyalizm, hazcılık, sadizm ve despotizmi besleyeceği kaygısı içindedir (Abdurrahman, 2014, 12).

\section{Taha Abdurrahman’ın Müzakere Etiği ve İletișim Teorisi Bağla- mında "Referans Bilgi [Me’sûl]" ve Transfer Bilgi [Menkûl] Kavramla-} rl

Müzakere etiği, rasyonalizmin bir modelini oluşturmaktadır. Taha Abdurrahman'ın müzakere etiğine yönelmesinin nedeni, bu anlayışın, değerleri nötralize eden objektif eğilimli bilimsel pozitivizmin sunduğu modelden farklı olmasıdır. Aynı zamanda Taha Abdurrahman açısından müzakere etiği, İslam düşüncesinin karşı olduğu "araçsal akılcılık (instrumental rationalism)" ve ondan kay- 
naklanan kavrayış tarzından da başka bir şeydir. Zira araçsal akıl, modern bilinci, çarpitmalarla malul ontolojik bir yüzeyselleșmeye mahkûm etmektedir (Mellouk, 2018, 108).

Din, bir taraftan kişilerin özgür iradeleri ile benimseyecekleri bir yapı, diğer taraftan insan hayatını çepeçevre kuşatan bir sistem olarak madde ve ruhu, birey ve aile hayatını, siyaset ve kamusal alanı birleștiren ve her birine taabbüdî bir neşve katan bütüncül bir çerçeve çizmektedir. Bu itibarla din, hurafelerle ve hakikati karartan güçlerle ilişkilendirilemez. Dinî akıl ise Kur'ân'ın, “Dünya yaşayışının yalnız dış yüzünü bilirler ve onlar, ahiretten gâfil olanlardır." (Kur’ân-ı Kerîm Meâli, 2009, er-Rûm 30/7) diye ifade ettiği araçsal akılla arasına kapanmaz bir mesafe koyar. Ayrıca din, makâsıdından kopartılarak ilâhî buyruğun statikleștirilmesini kabul etmemektedir. Bu doğrultuda Taha Abdurrahman, bireyin, tarihin dışında gerçekleşmiş Elest Bezmi'ndeki şehâdetini referans almak suretiyle, bir yönüyle selefîlerle ortak şekilde benimsemiş göründüğü, buyruğun değerinin, buyuranın statüsü ile ilgili olduğu görüşünü, sosyal şartlara bağlı bir makâsıd anlayışı ile uzlaştırmaya çalışmaktadır. İnsanın kendi tercih ve inisiyatifine bağlı olsa da dindarlık, [Elest Bezmi'ndeki misak ve ruhlara nakşedilmiş ilâhî varlığın bilgisi dikkate alındığında] kesbî, yani sonradan kazanılmış olmayan, yaratılıșa ait fitrî bir davranıştır (Abdurrahman, 2013, 52). Aslında Taha Abdurrahman kendi kurduğu ahlâkî paradigmasının (i'timaniyye) diğer paradigmalara göre çok daha rasyonel ve realist olduğunu söylemektedir. Onun, araçsal akıl kavramı ile ilgili olarak eleştirel biçimde söyledikleri, aklı aşkın boyuttan koparan ve onu salt profan bir dünyaya mahkûm eden anlayışla ilgilidir. Bu noktada Habermas'ın akla ilişkin stratejik modellemeler konusunda dile getirdikleri hatırlanmalıdır. "Aklın yerleşikleştirilmesi, hem Dilthey'den Heidegger'e kadar tarihsel düşünce geleneğinde hem de Peirce'den Dewey'e (ve bir şekilde Wittgenstein'a) kadar pragmatik düşünce geleneğinde, bilen öznenin aşkınlıktan koparılması görevi olarak anlaşılmıştır. Sonlu özne, "dünya üreten" kendiliğindenliğini tamamen yitirmeksizin, "dünyada” yerleşik olmalıdır. Bu açıdan McCarthy ile Heidegger, Dewey ve Wittgenstein'in öğrencileri arasındaki ihtilaf, hangi tarafın aşkınlıktan koparmayı doğru şekilde gerçekleştirdiği sorusu üzerine bir aile kavgasıdır (Jürgen Habermas, 2019a, 28).

Habermas, genel itibarıyla kökleri Locke'cu geleneğe dayanan ve bugünün neo-liberalistleri tarafından yenilenmiş olan sübjektif haklarla ilgili eleştirilere, hak verir görünse de ferdin, her türlü topluluktan önce ve haklarla birlikte doğduğunu varsayan metafizik safradan kurtulması gerektiğini bizzat savunur. Bu çerçevede fundemantalist şekilde yorumlanan İslam, Hıristiyanlık ve Yahudilik anlayışına göre hakikat mutlaktır. (Oysaki Habermas mutlak hakikati değil, müzakereye dayalı kolektif doğruyu referans alır). Dinsel mutlak hakikat anlayışı ise gerektiğinde şiddeti meşru kılar. Habermas, John Rawls'ın kavramsallaştırmasına atıfla dinin "makul bir doktrin" hâline gelmesi gerektiğini söyler (Habermas, 2018b, 168, $169,171)$. Bunun şerhi, mutlak hakikatin kolektif doğru ile ikamesi olup söz konusu tutumun, dinî görüşü seküler söylem içinde makul hâle getirmesidir. Buna mukabil Taha Abdurrahman aşina olduğumuz "akılcılık" ve "gerçekçilik" kavramlarının, aslında tek bir düzeyde olmadığını savunur. Aynı şekilde bu kavramlar tek tip 
olmayıp bunların farklı şekil ve türleri bulunmaktadır. Gerçekte akılcılık, akla dayalı bilginin ya da rasyonel temellere dayalı epistemolojik alanın değișmesi ile zorunlu olarak değişir. Böylece eskiden rasyonel ve akla uygun olan şey, zamanla irrasyonel ve akla aykırı olmakta, bunun tam tersine geçmişte irrasyonel olan şey, zamanla rasyonel ve makul hâle gelebilmektedir. Bu itibarla akılcılık, aklın sabit ve statik olması değil, tersine aklın çeşitli süreçlerden geçerek evirilmesidir. Buna göre aklını değişime tâbi tutmayan ve buna rağmen rasyonellik iddiasında olan kişi, aslında aklını kullanan akılcı ve rasyonel biri değildir. Aşina olduğumuz "akılcılık", nefse dayalı bir akılcılıktan ibarettir. Çünkü böylesi bir akılcılık, zâta nisbet [nisbet-i zâtiyye] olgusunu, kendisine referans almaktadır (Abdurrahman, 2012a, 505-506). Habermasın dinî söylemin seküler söylem içerisinde aklîleștirilmesi tezi, bu sefer, paradoksal şekilde seküler söyleme dayalı bir mutlaklaştırma hatasına düşmektedir.

Taha Abdurrahman, ideal bir iletişim topluluğu arayışı içindedir. 0 bu arayışında, Habermas gibi toplumu asıl, devleti fer olarak görmektedir (Abdurrahman, 2012a, 302). Ne var ki Taha Abdurrahman açısından ideal topluluk, dinî entelektüelleşmenin ifadesi olan tefakkuha bağlı bir epistemolojik difüzyondan ya da başka bir deyişle bilginin kapsamlı ve sistematik yaygınlık kazanmasından beslenir. Tefakkuh, dinî ve taabbüdî bilgiyi, İslâm kültürünün içinden referans bilgi (me'sûl) olarak görmekte ve başka kültürlerden transfer edilmiş olan bilgi (menkûl) unsurunun, bu kültürel veri tabanına göre konumlanması gerektiğini öngörmektedir. Haddizatında bu veri tabanı, yerli olsun yabancı olsun, her epistemeye etki eder ve onu yönlendirir. Me'sûl ve menkûl kavramlarl, gerçekte İslâmî pragmatiği tamamlayan iki epistemolojik veçhedir (Abdurrahman, 1994, 307; Abdurrahman, 2012a, 435-436). Doğrusu İslâmî bilimsel ve kültürel birikimin bir ifadesi olan pragmatiğin temelini teşkil eden referans bilgi ya da me'sûl, öncelikle birbirini tamamlayıcı unsurlar olarak vahyin bilgisi ve nebevî sünnetin oluşturduğu bilgi alanıdır. Lengüistik bir temele kuvvetli atıfları olan bu iki bilgi alanından metlüv olan vahyin bilgisi, yani Kur'ân-ı Kerîm, "i'câz" özelliği; gayru metlüv bir vahiy olarak sünnet ve bunun literal boyutu olan hadis ise "îcâz" özelliği taşır. Üçüncü bir alan olarak istişhâd unsuru olan dilsel alan ya da başka bir ifade ile nahiv ve belagat (elArabbiyye) ise İslâmî pragmatik açısından bir matriks niteliğindedir. Taha Abdurrahman'a göre bu son alan, pragmatik alanın terimi ile ifade edilecek olursa sözün eylemleşme sürecinde "başarı (incâz)" kavramı ile ilişkilendirilmelidir. Dolayısıyla incâz kavramı, i'câz ve îcâz olgularına kuvvetli atıflar içermekte ve bir ölçüde John Searl ve Austin gibi dil teorisyenlerinin söz eylem teorileri bağlamındaki "başarı" kavramına denk düşse de İslâmî pragmatik içerisinde kendine özgü bir kavramsal alan oluşturmaktadır. Son tahlilde bu kavram, İslâm düşüncesi bağlamında nassın aktüel yönü ile sahih ve müsellem bilgi üretimini ve iletişimin kolektif başarısını ifade etmektedir.

Taha Abdurrahman'a göre, İslâmî pragmatik açısından menkûl, yani transfer bilginin üç temel özelliği bulunmaktadır. Bunlar: Çeşitlilik (tenevvu'), etkileşim (tefâ'ul) ve sürekliliktir (istimrâr) (Abdurrahman, 1994,237). Taha Abdurrahman, genellikle transfer edilmiş bilginin, temel aktörü olarak, Yunan mantığı ve Yunan 
etik anlayışını öne çıkarmaktadır. Bu itibarla en soyut nazarî menkûlâtı ifade eden Aristo mantığl, -referans bilgi (me'sûl) hâline getirilme ideali içerisinde-İslâm düşüncesinin temel dinamiklerine dönüştürülmeye çalışılmış, en amelî ve normatif menkûlâtı ifade eden Grek etiği ise aynı gayeye matuf aslî unsur hâline getirilmek istenmiştir. İlki tecrîd-i nazarî, ikincisi tesdîd-i amelî nitelemesi içinde değerlendirilebilecek olan bu iki alan, farklı spekülasyonlara konu olmuştur. Ne var ki her halükârda transfer bilgi, referans bilgiye tâbi olmak zorundadır. Fakat tarih içerisinde referans bilgiyi, transfer bilgiye tâbi kılma hatasına düșen İslâm düşünürleri bulunmaktadır. Bu hata, Taha Abdurrahman'ın terminolojisinde takrîb-i ma'kûs (bilginin tersi istikamette konumlandırılması) olarak anılır (Abdurrahman, 1994, 237-238). Bu durum, iletişimsel açıdan da büyük bir hatadır.

Abdurrahman'a göre, aklın üç kategorik seviyesi bulunmaktadır. Bunlar sırasıyla mücerred, müsedded ve müeyyed akıl seviyeleridir. İnsanların hayattaki pozisyonları, aklın farklı mertebelerine göre bir nisbet durumudur. İnsan mücerret akıl kategorisine göre hayatını tanzim ederse bu süreci kendi nefsine nisbet etmiş olur. Mücerred akıl, seküler paradigmanın aklıdır ve bu, araçsal akla denk düşer (Abdurrahman, 2012a, 396). Kur'ân-ı Kerîm'de Velid b. Muğîre el-Mahzûmî mücerred aklı vasıta edinen en tipik inkârcı örneklerinden biri olarak sunulur (Müddessir 74/11-25). Mücerred akıldan daha yüksek mertebedeki müsedded akıl ise din ve siyasetin birbirinden ayrıștırılmaması gerektiğini söyleyen siyasal İslâm paradigmasının aklıdır. Bu aklın nisbeti, görünüște Allah Resûlü'nedir. Bu durum, elbette makbul bir şeydir. Ne var ki çoğu insan, müsedded akıl vasıtasıyla eylemlerini, -dinî nas böyle buyurdu- diyerek Hakk'a nisbet eder görünse de gerçekte onlar yaptıkları şeyleri, benimsedikleri liderlerine nispetle yapmaktadırlar. Böylece onlar siyasal yapının ürettiği dolaylı halkî nisbet ilkesini kendilerine referans almışlardır. Oysaki kişi, bütün bunların üstündeki müeyyed akıl mertebesinden hareket ederse o zaman akıl hiyerarşisinin en üst kategorisi olan bir akıldan yola çıktığı için hayatın anlamını ve bireysel arınma sürecini yüce Allah'a nisbet etmiş olur. Kişinin bir ideal olarak mücerred akıl ve müsedded akıl mertebelerini aşarak müeyyed akıl mertebesine ulaşması beklenir. Müeyyed akıl, fiilleri sadece yaratıcı ve rızık veren Hakk'a nisbet eder (Abdurrahman, 2012a, 270, 396; Abdurrahman, 2012b, 94). Siyasal İslâm'ı benimsemiş pek çok dindar, müeyyed akıl seviyesine çıkamadığı için müsedded akıl düzeyinde nassa istinat etmekte, en azından böyle görünmektedir. Gerçekte ise o, aklî nazar ve ahlâkî maslahat kavramlarının arakesitinde araçsal aklın tutsağı olmaktadır. Oysaki Taha Abdurrahman'ın ahlâkî bir model olarak önerdiği ilâhî sözleşme ve emanet paradigması, temellük ve tahakkukun gerçek sahibinin Allah olduğunu düşünmek suretiyle vasıtayı devre dışında bırakarak gayeye ulaşmaktadır.

Taha Abdurrahman açısından hiç kimse ilâhî sözleşme ve emanet paradigmasının vaat ettiği tercihin, insanı, onun elinden her tür tercih hakkını alan Cebriye anlayışına düşüreceğini söyleyemez. Zira kendi iradesi ile fiillerini tercih eden ilâhî sözleşme ve emanet paradigmasını benimsemiş kişi, bu paradigmayı benimsemeyen bir kişinin fiillerini tercih şeklinden farklı olarak kendi tercih aktivitesini, iki farklı katmanda pratiğe dökmektedir. Bu katmanlardan biri, varoluşsal ve kozmik 
katman; diğeri ise metafizik ve şuhûdî katmandır. 0 , müsedded akıl vasıtasıyla yürüdüğü varolușsal ve kozmik katmanda fiilleri hakkında sadece katıksız saf iradesi (mahz-ı irâde) ile bu tercihlerini gerçekleștirmektedir. Kendi iradesi ile fiillerini tercih eden ilâhî sözleșme ve emanet paradigmasını benimsemiş kiși de ilahî sözleşme paradigmasını benimsemeyen bir kişinin, mücerred aklı ile hareket ederek tercihlerini gerçekleştirmesi gibi bu katmanda tercihlerinin muhtemel sonuçlarına katlanmaktadır. Zira bu katmanda asıl olan tercihte bulunmak, yani ihtiyârdır. Buna mukabil o, müeyyed aklı, yani ruhu ile manevî bir miraç hâlinde yükselmiş olduğu metafizik ve şuhûdî katmanda ise bu fiillerini ıztırâr ve zorunluluk hâli içerisinde gerçekleştirmektedir. Fakat bu, söz konusu katmanın hem önsel ilahî tercihin cereyan ettiği bir mahal olması hem de bu mahallin, insanın tercihte ıztırârı ve zorunluluğu olmaksızın kendisi için tercihte bulunmaya mâlik olduğu bir yer olmasından dolayıdır. Taha Abdurrahman aklî mertebeler itibarıyla bir beșerî tercih kademelendirmesi yapmak suretiyle elindelik ve özgürlük problemini çözümlemek istemektedir. $\mathrm{Bu}$ anlatılanların bir özeti olarak ilâhî sözleşme ve emanet paradigmasının öngördügü fiillerdeki özgür tercih yaklaşımı, gerçekte eylemlerinde tercihte bulunan insanın, aklî nazarına olan ilgisini araç, ahlâkî maslahatına olan ilgisini ise amaç edinme idealine yerleştirir (Abdurrahman, 2012a, 478-479). Sonuç olarak Taha Abdurrahman, hem dünyevî plandaki kelime-i şehâdet açısından ruhsal ve zihnî bir hafıza olarak hem de insan fiillerinin özgür irade ile olan ilişkisini açılklamak üzere Elest Bezmi'ni bir mihver yapmış görünmektedir. Aynı zamanda o, inanan bir insan için nassın zâhirî bilgisi ile kayıtlı müsedded akıl kategorisinin, ruhî ve bâtınî bir derinlik ve tasavvur ile müeyyed akla evirilmesi açısından da şehâdete dayalı Elest Bezmi olgusunu önemsemektedir. Dolayısıyla onun Elest Bezmi, soyut ve ahistorik bir olgu olmaktan çok, insan eylemi açısından dinamik bir olgudur. Ne var ki ilk şehadette insanın tanıklığının yanı sıra Tanrının tanıklı̆̆ının bulunması ve insanın tanıklığına Tanrının şahit kılınması (işhâd), beșerî eylemi seküler araçsal akıl düzeyinden ilâhî boyutla ilişkili bir mertebeye taşımaktadır. İnsanın özü ve ruhunun derinliklerinde kodlanmış ilâhî hakikat, tedsiye denilen maddî perdelenmeye maruz kalmadığı müddetçe ve farz ibadetlerin yanında nafile ibadetlerle desteklendiği takdirde -Nevâfil hadisine atıfla- aşağıdan yukarı bir istikamette beşerî eylemlerin algısal unsurları, metafizik bir boyuta intikal etmektedir. Hatta daha doğru tanımlama ile metafizik algı ve inayet, yukarıdan aşağıya bir istikamette insan idrakinin mihverine yerleşmektedir. Bu durum, hadisteki tutan el, gören göz gibi unsurların beşerî plandan yükseltilerek Allah'a izafesini açıklar mahiyettedir.

Taha Abdurrahman, materyalist sarmaldan sıyrılarak istidlâli dışlamadan bireysel özgürlük temeline dayalı kolektif bir yapı olarak şehâdeti öne çıkarmakta, kolektif özgürlük alanına dayalı bireysel bir yapı olmak üzere ise istidlâli de aşan bir kavramsal alana sahip tefakkuhu öncelemektedir. Taha Abdurrahman'a göre İslâmî iletişimin merkezî kavramı olan "tefakkuh" ya da "entelektüel düzeyde bilgi edinim süreci", bilimsel ve kültürel alan olarak kendisine İslâmî pragmatiği esas almaktadır. Nihayetinde şehâdet ve tefakkuh, epistemolojik çerçevede birbirini tamamlamaktadır. Taha Abdurrahman, şehâdeti ve tefakkuhu istidlâl olgusu ile bir 
bütün oluşturacak șekilde değerlendirmektedir. Zira Taha Abdurrahman, her șeyde olduğu gibi bilgi alanında da ayrıştırmaya karşıdır.

Taha Abdurrahman, eleștirilerini bilhassa gelenek içinde Fârâbî ve İbn Rüșd'e yöneltmekte ise de modern dönemde özellikle İslâmî bilgiyi beyân, irfan ve burhan şeklinde parçaladığı iddiasıyla Muhammed Âbid el-Câbirî̀yi hedef almaktadır. Taha Abdurrahman'a göre, Câbirî, Batı kültürünün çeşitli alanlarından üst yapı enstrümanlarını iktibas etmiş, Jean Piaget'in yapılandırmacı yaklașımından (constructivism); André Lalande'ın ve Gaston Bachelard'ın rasyonel epistemolojisinden ve Hegelci ve Marksist yapısalcılık ve tarih felsefesinden etkilenmiștir (Abdurrahman, 1994, 34). Taha Abdurrahman'a göre bilginin ayrıștırılmadığı bir tefakkuh sürecinde oluşmuş toplumsal yapı, birlikte yaşama tecrübesi edinerek, kendi içine gayrimüslimleri de dâhil edebilir. Bu ise düpedüz imânî bir rasyonalizmdir. Artık modern medeniyetin soyut ve mücerred akılcılığı devre dışı bırakılmış, nasla doğrulanmış "müsedded akılcılık" aşılmış, nihayet nasla teyid edilmiş en ideal akıl düzeyi olan "müeyyed akıl” seviyesine ulaşılmıştır (Abdurrahman, 2012a, 397). Böylece aklî istidlâl, şehâdetle; akıl, vahiyle; zâhir bâtınla ve fizikî dünya metafizik dünyayla birleștirilmiştir. Bazılarına bu tez oldukça ütopik görünebilir. $\mathrm{Ne}$ var ki Taha Abdurrahman, İslâmî pragmatik ile bu hayali realize etmek istemektedir.

\section{4. İletişimin Temel Parametreleri Olarak Şehâdet ve İstidlâl Kavram- larının Arakesitinde Müzakere Olgusu}

Taha Abdurrahman'ın şehâdete dayalı iletișim tezi, akıl-nakil karşıtlığını kabul etmemekte ve akla karşılık, haberi alternatif bir unsur olarak değerlendirmemektedir. Bilakis her iki kavram alanı birbirini tamamlamaktadır. Bu doğrultuda Taha Abdurrahman'ın "şehâdet iletişimi tezi", şehâdet ve istidlâl kavramları arasında eşleşmeyi gerektirmektedir. Dolayısıyla șehâdet iletişimi tezi, aklın, kendi yapısı ile akıl yürüten kişinin bizzat buna, kendi varlığı ile şehadette bulunması mekanizmasını bir araya getiren bir argümantasyon [istidlâl] sistemidir. Böylece fizikî görme ve basiret ya da "iç görüye dayalı görme"nin her ikisinden kaynaklanan idrak, birleştirilmiş olmaktadır. Taha Abdurrahman, "şehâdet iletişimi"ne bağlı olan tezinin, Habermas'ın "istidlâl ve argümantasyon iletişimi" çerçevesindeki tezine üstünlük noktalarını ise şu şekilde açıklamaktadır:

\subsection{Söylemde İstidlâl Fer İken, Șehâdet Asıldır}

Söylem, en az iki tarafla ilgili açık ya da kapalı birtakım gereklilikler içermeli ve her iki taraf özel bir bağlamda konuşmayı sıralı olarak gerçekleştirebilmelidir. Mantıkçıların fark ettiği bu karşılıklı gerekliliklerden biri, doğruluğa ve yalana ihtimali olan her haberî sözün, örtük ve gizli yapısı içerisinde "bil [i'lem]" emir kipi şeklinde bir fiili içermesidir. Örnek olarak, "Müzakere demokrasinin temelidir." dendiğinde bu sözün gizli yapısı, [zihnen bilme kipini ilave etmek suretiyle] "Bil ki müzakere demokrasinin temelidir." șeklindedir. Bu karşllıklılık gereğinin değerlendirilmesine bağlı olarak ortaya çıkan temel referans noktalarından biri, haberî cümledeki iletişim unsurunun, inşâî cümle gibi diğer cümlelerden daha gizli olma- 
sıdır. Nihayetinde haberî cümle, zahiri ile yetinilse otomatik bilgi sistemi şeklinde bilginin kalıba döküldüğü bir kiplilik durumu olarak ifade edilebilir. Bu doğrultuda müzakerenin eksenini oluşturan söylem argümanının, haberî sözlerden oluştuğu malumdur. Aslına bakılırsa "Bil" vb. fiil türevlerinin ifade ettiği ișlev, şehâdet olgusundan başka bir şey değildir. Bu fiil ile konuşucu, başkasına söylediği şeyi [üstü örtük olarak kendisinin de] bildiğine şehâdet etmektedir. Şehâdet kipi sözlerde bazen açık (tasrîhî) yer alırsa da bazen takdirî olarak bulunur. Öyleyse Taha Abdurrahman'a göre, müzakere ve iletişim, doğal olarak şehâdetten ve kişinin kendi vicdânî kabulünden ayrı düşünülemez (Abdurrahman, 2012a, 165).

\section{2. Şehâdet Vasitasıyla İletişim, İstidlâl [Argümantasyon] Vasitasıyla İleti- şimden Daha Kuvvetlidir}

İstidlâlî iletişim ya da başka bir deyişle argümantasyon iletişimi teorisi, epistemolojik tasavvura çöreklenen benlik felsefesinin yıkıcı sonuçlarından bir çıkış yoludur. Aynı şekilde şahitliğe dayalı şehâdet iletişimi, insanın bir başkasının bilgisine boyun eğmeksizin, bizzat kendi benliği ile yetinmek suretiyle kendisini "bağımsız bir bilen" olarak kabul ettiği liberal bilgi tasavvurundan bir çıkıştır. Bu itibarla şehâdet iletişimi, birtakım hususlarda (Habermas'ın ileri sürdüğü) iletişimsel eylem kuramından, iletişim açısından daha üstündür. Bu kapsamda birinci husus, şehâdetin ancak doğal dil aracılığı ile olmasıdır. Çünkü şehâdetin bilgisini elde eden, ancak inancı ve bilgisi konusunda şahidin sözünü referans alır. Hâlbuki istidlâl, mekanik bir matematik yöntemle kipleştirilebilirse, bu durumda dile ihtiyaç duyulmayabilir (Abdurrahman, 2012a, 167).

İkinci husus, şehâdet, ancak insanlardan bir grupla ilgili olabilir. Çünkü şahit, kendi şahitliği ile genellikle hazır hâlde bulunan bir tarafa veya birden çok tarafa yönelerek onların "kendisinden bilgisini talep ettikleri ya da bilmedikleri bir şey"in bilgisi ile onları çepeçevre kuşatmaktadır. Hâlbuki istidlâl, tek başına olabilir ve tek kişi kendi kanaatinin oluşmasıyla argümanını ortaya koyabilir. Bu bakımdan müzakere, mekanik bir istidlâl sürecinden çok, şehâdet temeline dayanmalıdır. Aslında bu da müzakerelerde fikir beyan edenlerin pekâlâ dinî nasları referans alabileceğini göstermektedir. Oysaki neo-pozitivistlerin gözünde [bırakınız kutsal metinlerin geçerlilik değerini], Hegel, Bradley ya da Heidegger'in "metafizik ifadeleri [dahi] -doğal dillerin sentaksının "mantıksal bir sentaks" olmaması nedeniyle- anlamsızlığa yol açmaktadır. Buna karşılık mantıkçıların ideal dili, Leibniz'in dediği gibi "cahillerin çenesini kapatır." [Bu ise] mantıksal açıdan kabul edilemez olan önermeleri, gramerin dışına çıkarır (Récanati, 2019, 16).

Şehâdet iletişiminin argümantasyona dayalı iletişimden daha üstün olduğunu gösteren üçüncü husus ise şehâdet iletişiminde müzakerecinin önündeki şeye şahit olmakla yetinmemesi, aynı zamanda kendisinin şahit olduğu şeye, diğerini de şahit kılmak istemesidir. Buna göre şehâdetinin yanında şahit tutma [işhâd] da olmalıdır. İşhâd olgusu, argümantasyon ilişkisini sağlamlaştırmaktadır. Buna mukabil "delil" kendi durumundan soyutlanarak içyapısı içerisinde burhan seviyesine ulaşacak kadar kuvvet kazansa, artık kendisi için delil getirilene de bizzat delil getirene de neredeyse ihtiyaç kalmaz. Öyle ki bu durumda istidlâl mekanizması in- 
sandan çok argümana yakın, argümantasyonun matematiği ise söylemden çok istidlâlin mantığına yakındır. Hâlbuki haber, şahitten asla ayrılmaz ve ancak onunla bilinir ve şahit de "belirleme süreci"nde habere delil teşkil eder (Abdurrahman, 2012a, 168).

\section{3. Şehâdetin, İstidlâle [Argümantasyona] Göre Müzakere ile Daha Sağlam Bir Bağı Vardır}

Gerçek anlamda şehâdet, ancak en az belli bir iddiada çekişen iki tarafın varlığını gerektirir. Nihayetinde bu, iki taraftan birinin lehine olmak üzere, çatışmanın karara bağlanmasıyla sonuçlanır. Çünkü şehâdet olgusunun adalet kurumuyla sıkı bir bağı vardır. Haddizatında "iddia" ya da "husumet" konusu olan şeye dayalı müzakere, çekişen tarafları ikna edecek kararlara ulaşmayı gaye edinen çeşitli tartışmaların örnek aldığı bir tartışma modeli ortaya koymaktadır. Buna mukabil istidlâl [argümantasyon] olgusu hiçbir çekişmenin olmadığı durumda da bulunabilir. Şehâdet, tasdik edilmiş ve doğruluğu kabul edilmiş nakledilen sözler olması itibarıyla hakikatin kendi içinde bulunduğu şeydir ve kendi varlığının olgu ve gerçekliği dışında şehâdette bir hakikat bulunmaz. Bu itibarla şahadetteki doğruluğun durumu bizzat müzakere ve iletişimdeki doğrulukla eșdeğerdir. Hâlbuki istidlâldeki [argümantasyondaki] doğruluk ve geçerlilik, iletişimsel doğruluktan daha genel bir kavramdır. Argümanlar müzakereye ihtiyaç duymaksızın haricî olgu ve gerçeklere mutabakattan doğruluğunu ve geçerliliğini elde edebilirler. Şehâdet, "ilişki", "adalet" ve "iç doğruluk" vasıtalarını referans alma bakımından müzakereye en yakın unsur olmanın yanında "demokrasi" pratiğine de en uygun olan şeydir. Müzakereye özgü tartışmaların gerçekleşmesinin, şehâdette istidlâldekinden çok daha etkili olduğu anlaşılmaktadır. Şehâdet olgusu, ilişkinin sağlamlığı, adaletin gerçekleşmesi, iç bünyedeki doğruluk ve geçerliliğin aktarılması konularında istidlâl mekanizmasından çok daha etkin ve güçlüdür. Bu ise demokrasi için şehâdet olgusunun, istidlâle göre daha uygun olduğunu göstermektedir (Abdurrahman, 2012a, 168).

\section{4. Şehâdet Olgusu, İstidlâli (Argümantasyonu), Müzakerede Genişlemenin Yıkıcı Etkisinden Korur}

Şehâdet, sadece bilginin aktarılmasının bir vasıtası değildir. Aksine o, bilgi kaynağı olarak da kabul edilmelidir. Şehâdette fesat ve bozukluk, istidlâldekinden daha kötüdür. Çünkü "fâsid şehâdet", "fâsid istidlâl"deki gibi "aklın gerekleri"ni bozacak hatalı bir şehâdet olmanın ötesinde, aynı zamanda "adaletin gerekleri"ni bozacak yalancı bir şehâdet olarak da görülür. Şahidin, kendi şehâdeti ile olan bağlantısı, istidlâlde bulunanın kendi delili ile olan bağlantısından daha kuvvetlidir. Çünkü şahit, istidlâl sahibinin delili ile olan durumunda olduğu gibi şehâdetine sadece kanaat getirmek ile yetinmez, muhtemelen o, şehâdetine vicdanî ve bilinçsel bir iman derecesinde bağlıdır (Abdurrahman, 2012a, 169).

\section{5. Şehâdet, Despotizmin Kötülüğünden Demokrasiyi Korur}

Demokrasi "bizzat halk tarafından halkın kendi kendini yönetmesi" olarak tarif edilmek suretiyle despotizmden uzak bir sistem olarak görülse de despotiz- 
min tezahür edebileceği tek bir yol yoktur. Bu çerçevede demokrasiyi en üstün bir forma taşıyabilecek olan ilkelerden biri, șehâdetin, müzakerede temel rükün olarak kabul edilmesidir. Bunun açılklaması ise şudur: Şehâdet, ancak başkasının varlığına bağlı olarak bulunur. Şehâdetin gerekçesi, ötekinin maslahatını sağlamak iken, hedefi ise adaleti gerçekleștirmektir (Abdurrahman, 2012a, 171).

\section{6. Șehâdet, İstidlâlin Değerini Yükseltir}

Şehâdette bulunarak istidlâl yapan kişi ile şehâdette bulunmadan istidlâl yapan kişi arasında çok fark vardır. Şöyle ki aynı anda hem şehâdette hem istidlâlde bulunan kişi, delilin, istidlâle yönelik özelliğini ortadan kaldırmadan, aksine istidlâle yönelik özelliği referans almak suretiyle bu delili haber mertebesine nakleder. Sanki o böylece ilk deliline ikinci bir delil eklemiş olur (Abdurrahman, 2012a, 171).

\section{7. Şehâdet, Müzakereciyi Adaleti Esas Alan Müzakereci Düzeyine Yüksel- tir}

Habermas'ın iletişim teorisine göre, müzakerede ne yapmamız gerektiğine karar verme keyfiyetimizi bize prosedür yöntemleri açıklayabilir. Habermas'ın bu konudaki durumu tıpkı çağdaşı Amerikalı filozof John Bordley Rawls'un durumu gibidir. Bu yöntemde demokratik prosedürün herkesin çıkarlarını dikkate alması ve Modus-Vivendi bir uzlașmaya varması yeterli görülmemiştir. Asıl amaç, bir iletişimsel iktidarın üretilmesidir. Ahlâkî tarafsızlığı garanti altına aldığı düşünülen prosedür yöntemleri değerini bu noktadan almaktadır (Mouffe, 2015, 92). Ne var ki Habermas ve Rawls'un iddiasının aksine söz konusu prosedür yöntemleri, sadece sûrî ya da başka bir deyişle formel yöntemler olarak kabul edilemez, tam tersine prosedür yöntemleri, bir ölçüde hayat tarzları ve davranış şekilleri ile de doğrudan ilişkili pratiklerden ibarettir. Böylece bu yöntemler, bizzat "adalet" ve "iyilik" arasında karşıtlık öngören tasavvurdan başlayarak, hakikatleri, değerler bütününü ve güzel hayata dair muhtelif tasavvurları kendisine referans almayı gerektirir. Mouffe'un, -özünde Wittgenstein'ın fikirlerine kadar uzanan anlayışı çerçevesindekurallar, daima pratiklerin özetidir ve özgül yaşam biçimlerinden ayrlamazlar. Zira Wittgenstein'a göre mutabakat, anlamlar (Meinungen) değil, ama yaşam biçimleri (Lebensform) üzerine tesis edilir. Habermas'çı yaklaşımda merkezî ayrımlar olarak sunulan prosedürel ile maddî olan ya da ahlâkî ile etik olan arasında tam bir ayrımın imkânsızlığı aşikârdır (Mouffe, 2015, 76, 101). Haddizatında pek çok etik, manevî ya da maddî unsur, daha derin tradisyonlarla ilişkilidir. Dolayısıyla toplumu, din gibi ön kabuller bağlamından kurtarma ve müzakereyi sırf kolektif ve önyargısız uzlașıya dayandırma iddiası, Habermas'ın iletișim teorisindeki prosedür yöntemlerinin, hayat tarzları ve davranış şekillerini büsbütün devre dışı bırakamadığı dikkate alındığında anlamsızlaşmaktadır. Taha Abdurrahman'ın iletişim modelinde ise müzakere ve iletişimde sadece mekanik prosedür yöntemleri değil, şehâdete dayalı olarak vicdanî tutum da devrededir. Öte yandan söz eylem teorisi bağlamında, hassaten İslâm düşüncesinde pragmatik alan, dinî birikim ve vahiy ile bağlantılı olmak durumundadır. 


\section{Sonuç}

Taha Abdurrahman açısından dinî değerlerin ve insan fitratına yerleştirilmiş hakikatlerin devre dışı bırakılması düşünülemez. Böyle bir tutum, doğrudan şehâdeti dışlamak suretiyle müzakereyi ve iletişimi, ideolojik manipülasyonlara açık şekilde tek taraflı bir yöntem olarak istidlâle mahkûm eder. Öte yandan gerçek anlamda şehâdet, ancak en az belli bir iddiada çekișen iki tarafın varlığını gerektirir. Nihayetinde bu iddia, iki taraftan birinin lehine olmak üzere, çatışmanın karara bağlanmasıyla sonuçlanır. Bu çerçevede demokrasiyi ve demokratik müzakereleri, en üstün forma taşıyabilecek olan ilkelerden biri, şehâdetin, müzakerede ve iletişim kanallarında temel rükün olarak kabul edilmesidir. Şehâdet, ancak başkasının varlığına bağlı olarak bulunur. Şehâdetin gerekçesi, ötekinin maslahatını sağlamak iken, hedefi ise adaleti gerçekleştirmektir. Habermas'ın demokrasi anlayışı, ahlâkî ve siyasal olarak eşit kabul edilen bireysel ve kolektif kimliklerin, kendi yaşam tarzlarını etkileyen kararlar üzerinde makul ve özgür sorgulama olanağı buldukları ve bu anlamda karar alma süreçlerine katıldıkları bir kamusal iktidar pratiğidir. Bu noktada Taha Abdurrahman, Habermas ile uyușmaktadır. Ancak Taha Abdurrahman'ın kendi iletişim teorisinde Habermas'tan ayrıldığı nokta, dinî birikimin iletişimde aktif hâle getirilmesidir.

Son tahlilde Taha Abdurrahman'ın geliştirdiği şehâdet iletişimi modeli, onun daha genel ahlâkî boyuttaki emanet paradigmasının iletişim boyutunu ifade etmektedir. Taha Abdurrahman'ın Elest Bezmi'ne dayalı emanet paradigması, ontolojik olduğu kadar, praksiyolojik, yani insanî eylemlerle de ilgidir. Öte yandan Taha Abdurrahman açısından "şehâdet" ve "istidlâl" kavramları, birbirlerine karşıt iki kavram alanı değildir. Bunlar birbirini tamamlamaktadır. Taha Abdurrahman'a göre bazı hususlarda şehâdet, istidlâlden de üstün özelliktedir. Nitekim şehâdet, sadece bilginin aktarılmasının bir vasıtası değil, bilginin kendisidir de.

Ayrıca şehâdet kavramına bağlı olarak, "metafizik değerlerin fizikî dünyaya aktarılmasının bir ifadesi olan teşhîd", "gelecekte olanı tahayyül etmek" değil, "geçmiştekini hatırlama (tezekkür)" faaliyetidir. Buradan hareketle modern pozitif bilimler, akla ve duyulara dayalı daraltılmış metodolojilerine rağmen, dinin şehâdetle ilişkili hatırlamaya yönelik hafıza gücünü kabul etmek zorundadırlar. Bu itibarla Taha Abdurrahman, ısrarla "bilinç", "niyet" ve "özgürlük" kavramları üzerinde durmaktadır. Özellikle Elest Bezmi ile ilgili olarak, insanın en büyük eylemi olan ve Taha Abdurrahman'ın teorik yaklaşımına etimolojik bir dayanak niteliğinde olan "emanet" kavramı, insanın kendi tercihi ile gerçekleştirdiği bir eylemdir. Fakat bu eylem, ontolojik olarak onun kendi varlığını nefsî bir nispete dayandırmaz. Taha Abdurrahman'ın iletişim modelinde din, etik, akıl ve rasyonel eylem eşittir ve her biri eşit biçimde uygarlığa katkıda bulunmaktadır.

Taha Abdurrahman'ın düşünüş ilkeleri açısından dünya, mekanik determinizme mahkûm edilmiştir. Dinî ve teolojik telos, seküler toplumlarda gerçek dişı bir idealleștirme olarak görülmüștür. Tanrı'nın mutlak otoritesinin reddi, seküler zihinlerde beșerî özgürlük olarak algılansa da İslamî paradigma açısından henüz Elest Bezmin'den itibaren şehâdet olgusuna dayalı beşerî eylemlerin, özgür iradeyi referans aldığı kabul edilmek suretiyle fatalist anlayış yıkılmıştır. Seküler tutumun 
insanlığı fatalizmden kurtarma çabası şehâdet olgusu dışlanarak mümkün görünmemektedir. Zira sekülarizm fatalizmden kaçarken insanı despotlaștırmakta ve insanlık mekanik determinizme mahkûm edilmektedir. Sekülerizm, kâinatın işleyişi, gök cisimlerinin hareketi, yağmur duası, sünnetullah kavramı ekseninde tarihsel olayların nedensel dizgeye yerleştirilmesi gibi hususlar çerçevesinde dinin gayeci ya da ereksel düşünüş şekli ile bilimin araçsallığından ayrıldığı şeklinde din kavramına ve özelde İslam'a suçlama yöneltmektedir. Bașka bir deyișle modernitenin erek ve araç ayrıştırması bağlamında bilim, araçsal bir yapı olarak ele alınmakta ve erek ve amacın odak nokta olduğu din, seküler hayatın dışına itilmeye çalışılmaktadır.

Nihayetinde seküler dünya görüşü ve modernite, insan hayatına, sadece beşerî varlığı esas almasını dikte ederek, özgürlük vaadiyle yola çıksa da bu anlayış, özgürleştirme projesi adı altında tüm hayat alanlarını kolonize etmekte, insanın kulağına “ben olmadan 'sen' olamaz (ve vice versa)” anlayışını fisıldamaktadır. Taha Abdurrahman'ın paradigması açısından ise her şeyi nefse nisbet etmenin değil, Allah'a nisbet etmenin gerekliliğine vurgu yapılmaktadır. Taha Abdurrahman, temel dinamiklerini naslardan alan, fakat çok boyutlu referans ağına sahip bir siyaset ve ahlâk paradigması, bunun yanında ise şehâdet ve istidlâli beraberce değerlendirdiği bir müzakere etiği ve medya teorisi ortaya koymaktadır. Daha doğru bir adlandırma ile o, bir praksis inşa etmektedir. Bu praksis, insanı, makâsıdı ahlâk olan bir eylem alanına yöneltmektedir. Taha Abdurrahman, insanın alışageldiği soyut akla hitap etmemekte ve o, ruh ile desteklenmiș olan beşerî akla seslenmektedir. Nihayetinde bize, insanın tek boyutta varlık bulmuş olmadığını hatırlatarak, onun fiziksel ve metafiziksel boyutlara sahip çok boyutlu bir varlık olduğunu söylemektedir. Dahası Taha Abdurrahman, iletişim alanını olabildiğince genișleterek, insanın, yerlerde sürünen bir sürüngen olmaktan çok, göklerde uçmayı hak eden bir canlı olduğunu ifade etmektedir. Böylece beşerî iletişim, salt mekanik bir istidlâl anlayışına mahkûm edilemeyecek kadar derin bir örüntü içerisindedir. Dolayısıyla İslâmî iletişim, müzakere etiği ve medya kavramı, profan retorikle sahte şekilde nesnelleştirilmiş bir normatif anlayışı aşan, vicdanî, imânî ve ahlâkî bütünlük içinde değerlendirilmelidir. $\mathrm{Bu}$ çerçevede müzakere ve iletişim olguları, istidlâl kadar, insanın şâhitliğini ve imanını ifade eden bir kavram olarak, kaynağını metafizik ilkeden alan şehâdete dayandırılmalıdır. Bu çerçevede gerçekleştirilecek bir müzakere ve iletişim sürecinin başarı elde etme imkânı çok daha fazladır.

Author Contributions / Yazarların Katkısı: This article is a work with twoauthors. The contribution of the aforementioned authors to the preparation of the article is equal. / Bu makale, iki yazarlı bir eserdir. Makalenin hazırlanmasına söz konusu yazarların katkısı eșittir.

Funding / Finansman: This research received no external funding. / Bu araștırma herhangi bir dış fon almamıştır.

Conflicts of Interest / Çıkar Çatışması: The author declare no conflict of interest. / Yazar, herhangi bir çıkar çatışması olmadığını beyan eder. 


\section{Kaynakça}

Abdurrahman, Taha. Bu'sü'd-dehrâniyye: en-nakdü'l-i'timânî li-fasli'l-ahlâk 'ani'd-dîn. Beyrut: eş-Șebeketü'l -Arabiyye li'l-ebhâs ve'n-neșr, 2014.

Abdurrahman, Taha. Dînül-hayâ: mine'l-fikhi'l-i'timârî ile'l-fikhi'l-i'timânî. Beyrut: elMüessesetü'l-Arabiyye, 2017.

Abdurrahman, Taha. Rûhu'd-dîn min dayki'l-almâniyye ilâ se'ati'l-i'timâniyye. DârülbeyzâKazablanka: el-Merkezü's-sekâfî el-Arabî, 2012a.

Abdurrahman, Taha. Suâlü'l-amel: bahsun ani'l-usûli'l-ameliyye fi'l-Fikri ve'l-ilm. DârülbeyzâKazablanka: el-Merkezü's-sekâfî el-Arabî, 2012b.

Abdurrahman, Taha. Tecdîdü'l-menhec fî takvîmi't-turâs. Beyrut: el-Merkezü's-sekâfî elArabî, 1994.

Âmidî, Seyfüddîn. el-İhkâm fî usûli'l-ahkâm. Beyrut: el-Mektebü'l-İslâmî, 1402.

Dworkin, Ronald. "Sivil İtaatsizliğin Etiği ve Pragmatiği". Kamu Vicdanına Çağı Sivil İtaatsizlik. çev. Yakup Coşar. 144-165. İstanbul: Ayrıntı Yayınları, 2018.

Habermas, Jürgen. Doğalcılık ve Din Arasında: Felsefí Denemeler. çev. Ali Nalbant. İstanbul: Yapı Kredi Yayınları, 2019a.

Habermas, Jürgen. Sosyal Bilimlerin Mantığı Üzerine. çev. Mustafa Tüzel. İstanbul: Alfa Yayınları, 2018c.

Habermas, Jürgen. "Kamusal Alanda Din-Religion in the Public Sphere". çev. M. Ali Kirman. Şırnak Üniversitesi İlahiyat Fakültesi Dergisi 7/14 (2016), 183-206. https://dergipark.org.tr/tr/download/article-file/412495

Habermas, Jürgen. "Sivil İtaatsizlik: Demokratik Hukuk Devletinin Denektaşı. Almanya'da Otoriter Legalizm Karşıtlığı”. Kamu Vicdanına Çă̆ı Sivil İtaatsizlik. çev. Yakup Coşar. 122-144. İstanbul: Ayrıntı Yayınları, 2018d.

Habermas, Jürgen. Bölünmüş Batı. çev. Dilman Muradoğlu. İstanbul: Yapı Kredi Yayınları, 2006.

Habermas, Jürgen. İdeoloji Olarak Teknik ve Bilim. çev. Mustafa Tüzel. İstanbul: Yapı Kredi Yayınları, 2019d.

Habermas, Jürgen. İletişimsel Eylem Kuramı. çev. Mustafa Tüzel. İstanbul: Alfa Yayınları, 2019b.

Habermas, Jürgen. Kamusallığın Yapısal Dönüşümü. çev. Tanıl Bora - Mithat Sancar. İstanbul: İletișim Yayınları, 2018a.

Habermas, Jürgen. Küreselleşme ve Milli Devletlerin Geleceği. çev. Medeni Beyaztaş. İstanbul: Yarın Yayınları, 2018b.

Habermas, Jürgen. Öteki Olmak, Öteki ile Yaşamak: Siyaset Kuramı Yazıları. çev. İlknur Aka. İstanbul: Yapı Kredi Yayınları, 2019c.

Habermas, Jürgen. Söylem Etiği. çev. Seyit Coşkun. Ankara: Fol Kitap, 2020.

Kefevî, Ebü’l-Bekâ. el-Külliyyât. thk. Adnan Derviș. Beyrut: Müessesetü'r-Risâle, ty.

Mellouk, Abdulkadir. "Fi'l-bahs an müşterek ahlâkî kevnî: Putnam, Habermas ve Taha Abdurrahman". Tabayyun 6/24 (Spring 2018), 97-120.

Mouffe, Chantal. Demokratik Paradoks. çev. A. Cevdet Aşkın. Ankara: Epos Yayınları, 2015.

Récanati, François. "Mantıkçı Pozitivizmden Gündelik Dilci Felsefeye: Pragmatiğin Doğuşu”. Söz Edimleri Seçilmiş Yazılar. hzl. Atakan Altınörs. İstanbul: Bilge Yayınları, 2019.

Specter, Matthew. Habermas: Entelektüel Bir Biyografi. çev. İsmail Ilgar. İstanbul: İletişim Yayınları, 2012.

Yıldırım, Yılmaz. "Jürgen Habermas'ın İletişimsel Eylem Kuramı". Afyon Kocatepe Üniversitesi Sosyal Bilimler Dergisi 8/2 (2006), 249-268.

Yükselbaba, Ülker. Habermas'ta Kamusal Alan Ayrımı. İstanbul: İstanbul Üniversitesi, Sosyal Bilimler Enstitüsü, Doktora Tezi, 2008. 